\title{
Financing Constraints and Unemployment: Evidence from the Great Recession*
}

\author{
Burcu Duygan-Bump, Alexey Levkov, and Judit Montoriol-Garriga
}

First Version: 8 October 2010

This Version: 14 December 2011

This paper exploits the differential financing needs across industrial sectors and provides strong empirical evidence that financing constraints of small businesses in the United States are important in explaining the unemployment dynamics during the Great Recession. We show that workers in small firms are more likely to become unemployed during the 2007-09 financial crisis if they work in industries with high external financing needs. We find very similar results for the 1990-91 recession, but not for the 2001 recession, where only the former was associated with a reduction in loan supply. These findings further support the credit constraints hypothesis.

Keywords: Recession, Firm Size, Financial Dependence, Unemployment

\footnotetext{
* Duygan-Bump and Levkov are from the Federal Reserve Bank of Boston. Montoriol-Garriga is from Universitat Autonoma de Barcelona. For their helpful comments, we would like to thank Ashwini Agrawal, Patrick de Fontnouvelle, Jeff Fuhrer, Simon Gilchrist, Martin Goetz, Chris Foote, Gary Inamorati, Jim Nolan, Christina Romer, Eric Rosengren, Bob Triest, Christina Wang, Isaac Weingram, as well as conference and seminar participants at the Atlanta Fed, Boston Fed, Boston University, Minneapolis Fed, St. Louis Fed, The Institute for Fiscal Studies, NBER Summer Institute (Monetary Economics), and Western Finance Association meeting. We would also like to thank Nicola Cetorelli and Philip Strahan for making available the data and the code for calculating external financial dependence. We thank Isaac Weingram for providing excellent research assistance. The views expressed in this paper are solely those of the authors and do not necessarily reflect official positions of the Federal Reserve Bank of Boston or the Federal Reserve System. Please address correspondence to Alexey Levkov at $<$ Alexey.Levkov@bos.frb.org $>$.
} 


\section{Introduction}

Lending to small businesses in the United States has fallen dramatically since the onset of the Great Recession. Between the second quarter of 2008 and the second quarter of 2010, small business loans made by commercial banks declined by over $\$ 40$ billion. Recent evidence suggests that much of the decline in new lending reflects changes in the supply of credit (Ivashina and Scharfstein 2010, Huang and Stephens 2011). Similarly, the responses to the Federal Reserve's Senior Loan Officer Opinion Survey on Bank Lending Practices indicate that banks have significantly tightened credit standards on Commercial and Industrial loans to small firms in thirteen consecutive quarters between 2007:Q1 and 2010:Q1. ${ }^{1}$

The decline in small business lending has received much attention from policy makers and the media, especially because of its potential link to the high rate of unemployment. Indeed, almost $80 \%$ of all firms in the U.S. have fewer than nine employees, and small firms employ roughly $50 \%$ of non-farm private sector workers. $^{2}$ Unlike larger firms, which have broader access to capital markets, small businesses are highly dependent on bank financing. ${ }^{3}$ An important implication is that any kind of disruption in the flow of bank credit may have significant real effects on the labor market.

In this paper we investigate the link between small business lending and unemployment during the Great Recession in the United States. We identify credit supply effects by using industry-level measures of external financial dependence following the work of Rajan and Zingales (1998). If the reduction in small business lending affects employment, then workers in smaller firms are more likely to be affected, primarily those working in firms that depend on

\footnotetext{
${ }^{1}$ Small business lending figures are from Consolidated Reports of Condition and Income, where small business loans are defined as loans with original amounts of $\$ 1$ million or less. The responses to the Senior Loan Officer Opinion Survey on Bank Lending Practices are from Figure 1 in the October 2011 report.

${ }^{2}$ See the speech by Federal Reserve Chairman Bernanke on July 12, 2010 in Washington, D.C. and U.S. Census Bureau, Statistics of U.S. Businesses for 2007.

${ }^{3}$ See, for example, Petersen and Rajan (1994), Cole, Wolken, and Woodburn (1996), Berger, Klapper, and Udell (2001).
} 
bank financing. We test our hypothesis by combining information on workers' firm size and employment status from the Current Population Survey with firms' financial information from Compustat and the Survey of Small Business Finance. We then estimate the likelihood of becoming unemployed during the recent financial crisis across industrial sectors with different degrees of external financial dependence, separately for small and large firms.

Our approach is a triple difference-in-differences methodology which exploits variation across time, firm size, and firms' financing needs. The third difference is especially useful because it helps isolate factors that affect the likelihood of switching to unemployment differentially by firm size. It is possible, for example, that the reduction in the demand for goods and services during the recession fell disproportionately on small firms and therefore affected their likelihood of firing workers more than in large firms. Our estimates differenceout this potential effect as long as the decline in demand for goods produced by small firms was similar across industries with different degrees of external financial dependence.

We find that during the Great Recession workers are more likely to become unemployed if they work in sectors with high external financial dependence. In these sectors the impact of the recession on the likelihood of becoming unemployed is stronger for workers in smaller firms. By contrast, we do not find significant differences in unemployment propensity between workers of small and large firms in sectors with low external financial dependence. These results indicate that the reduction in bank lending to financially constrained firms during the recent financial crisis is associated with increased layoffs of workers. The findings are robust to different measures of external financial dependence.

While these results are consistent with a credit supply shock hypothesis, a potential confounding factor is a reduction on the demand side. Borrowers may be reluctant to expand their businesses, or may consider downsizing because of changes in the demand for their goods and services during the recession. This would lead to a reduction in their demand for loans and an increase in layoffs of workers. This channel may explain our findings if the reduction in 
the demand falls primarily on small, bank-dependent firms. Our methodology is specifically designed to address this issue as we divide firms by external financial dependence at the industry level. If small firms suffer larger declines in demand for their goods there is no evident reason this should primarily happen in sectors with high external financial dependence.

To provide further support for our interpretation of the findings, we repeat our analyses around the 2001 recession and the Savings and Loan (S\&L) crisis that led to the 1990-91 recession. We exploit the fact that the 2001 recession did not originate in banks' balance sheets and was therefore not associated with a reduction in loan supply. The S\&L crisis, on the other hand, did originate in the banking sector similarly to the Great Recession. If credit constraints are important in explaining transitions to unemployment during a downturn, we should find larger swings in unemployment for credit constrained firms in 1990-91 but not in the 2001 recession.

The findings from the 2001 and 1990-91 recessions are fully consistent with our hypothesis. The estimates around the 2001 recession show almost identical changes in unemployment among small and large firms in industries with high and low external financial dependence. However, the estimates for the 199091 recession show very similar patterns to the estimates from the 2007-09 analysis, where transition to unemployment is more pronounced among small firms in industries with high external financial dependence. For the 1990-91 recession we also exploit regional variation and focus on New England. The S\&L crisis was especially virulent in New England, a region that experienced sharp declines in real estate prices and whose banks faced large capital declines due to their exposure to real estate (Peek and Rosengren 1994). The results from this exercise show a steeper increase in unemployment in New England as banks responded to their deteriorated financial condition by shrinking their balance sheets and reducing credit availability in a very similar fashion to the Great Recession.

All of these results are consistent with a credit supply contraction hypothesis and highlight the importance of banks' financial health for credit availability and their impact on the macroeconomy, along the lines of Bernanke (1983), 
Holmstrom and Tirole (1997), and Peek and Rosengren (2000). Our paper also reinforces the conclusions in Gertler and Gilchrist (1994), who find that growth in sales, inventories, and bank debt of small manufacturing firms is more sensitive to monetary policy shocks than that of larger firms. Similarly, these findings are consistent with other studies that document the impact of credit constraints on investment spending (Fazzari, Hubbard, and Peterson 1988, Gertler and Hubbard 1988, Hoshi, Kashyap, and Scharfstein 1991, Whited 1992, Kashyap, Lamont, and Stein 1994, and Duchin, Ozbas, and Sensoy 2010) and employment (Sharpe 1994, Nickell and Nicolitsas 1999, Gozzi and Goetz 2010, Benmelech, Bergman, and Seru 2011, and Bascim, Baskaya, and Kilinc 2011). Methodologically, our paper differs from the latter papers in that we differentiate firms by both size and external financial dependence. Another difference is that we examine changes in employment focusing on the recent financial crisis as well as the 2001 and 1990-91 recessions.

The findings also relate to the vast literature that highlights the role of financial markets in shaping economic growth and in particular to the papers that analyze the mechanisms through which finance affects real economic activity. Examples include Jayaratne and Strahan (1996), King and Levine (1993), Levine and Zervos (1998), Rajan and Zingales (1998), Guiso, Sapienza, and Zingales (2004), and Cetorelli and Strahan (2006). Similarly, recent empirical evidence strongly suggests that during recessions industries with higher external financial dependence are hit harder in terms of production growth (Braun and Larrain 2005), value added (Kroszner, Laeven, and Klingebiel 2007), capital formation, and number of establishments (Dell'Ariccia, Detragiache, and Rajan 2008). A recent study of 1,050 Chief Financial Officers conducted by Campello, Graham, and Harvey (2010) indicates that financially constrained firms planned deeper cuts in employment in the midst of the recent financial crisis.

Our paper's key contribution is to emphasize the channels underlying the important role of finance in real economic activity, as we show that small businesses have been laying off workers in the current recession due to credit constraints. This result naturally relates to the literature on the real effects of 
the credit supply shock during the Great Recession. Duchin et al (2010), for example, find that investment declines significantly more for firms with low cash reserves during the crisis. Similarly, Almeida et al (2010) find that firms vulnerable to refinancing at the peak of the financial crisis reduce investment spending and bypass attractive investment opportunities.

We also contribute to the literature that focuses on the role of small businesses in job creation and labor markets. The academic literature in this area has mixed findings. Haltiwanger, Jarmin, and Miranda (2010), for example, show that small firms do not create jobs faster once firm age is accounted for. On the other hand, Neumark, Wall, and Zhang (2011) find an inverse relationship between net growth rates and firm size, though not in the manufacturing sector. Similarly, Moscarini and Postel-Vinay (2009) find that small businesses create more jobs in periods of high unemployment and recessions. Our paper highlights the importance of credit availability to achieve this outcome.

In the next section we describe our empirical strategy, the data, and the construction of measures of external financial dependence by industrial sectors. In Section 3 we provide descriptive statistics of the data and present our main findings. Section 4 describes various robustness tests where we look at two additional recession episodes, construct an alternative measure of financing needs, and estimate changes in the number of establishments instead of changes in unemployment. We conclude the paper in Section 5.

\section{Empirical Strategy and Data}

\subsection{Empirical Strategy}

Our econometric analysis is based on a specification of the following form,

$$
\begin{aligned}
y_{i j s t}= & \alpha_{j s}^{d}+\mathbf{x}_{i j s t}^{\prime} \boldsymbol{\theta}^{d}+\delta^{d} \text { recession }_{t}+\mu^{d} \text { small }_{i j s t-1}+ \\
& \rho^{d}\left(\text { recession }_{t} \times \text { small }_{i j s t-1}\right)+u_{i j s t}^{d}
\end{aligned}
$$


where $y_{i j s t}$ is an indicator that equals to one if person $i$ - whose main industry of occupation in the previous year was $j$ and who currently resides in state $s$ - switched from employment to unemployment between the years $t-1$ and $t$. Employment in year $t-1$ means that the person was employed at some point during the previous year. Unemployment in year $t$ means that the person is unemployed in the month of March of year $t$ in the week before she was surveyed by the Current Population Survey. $y_{i j s t}$ takes the value of zero if person $i$ is employed both in $t-1$ and $t .^{4}$

$\alpha_{j s}$ are industry-state fixed effects that control for industry-state time invariant observable and unobservable factors that impact the probability of switching from employment to unemployment. The vector of characteristics $\mathbf{x}$ controls for workers' observable differences in age, gender, ethnicity, and years of completed education. Controlling for these characteristics is important because the propensity of becoming unemployed in the 2007-09 recession has not been equal across age, gender, ethnicity, and education. According to the $\mathrm{Bu}-$ reau of Labor Statistics, the unemployment rate among ages 16-19 increased by 11 percentage points between January 2006 and January 2010, while the overall increase in the unemployment rate for the same period was 5 percentage points. Similarly, the unemployment rate among high-school dropouts aged $25+$ increased by 8 percentage points, while for college graduates it increased by less than 3 percentage points. ${ }^{5}$

We analyze the transition from employment to unemployment around three recession episodes in the United States: July 1990 - March 1991, March November 2001, and December 2007 - June 2009. For each recession we use a five-year window of three years before the recession and two years during or

\footnotetext{
${ }^{4}$ Respondents to the Current Population Survey (CPS) self-report their employment status in the week before the interview. In the March supplement to the CPS, respondents are asked about the size of their main employer in the previous year. Respondents who provide information on the size of their main employer must have been employed at some point during the previous year, but there is no information on the exact period.

${ }^{5}$ In our specification ethnicity is an indicator that equals to one if the person is white and equals to zero otherwise. We use the following categories for years of completed education: $0-11,12,13-15,16$, and $17+$. We use the categorical and not continuous version of years of completed education because of the redesign of the CPS in the early 1990s. See Polivka (1996) for details.
} 
following the recession. Importantly, we observe transition from employment to unemployment only in the month of March of every year. We estimate equation (1) separately for each recession episode. Thus, for the 1990 recession, the recession indicator in equation (1) equals to one in the years 1991-92 and equals to zero in the years 1988-90; for the 2001 recession, the indicators equals to one in the years 2001-02 and equals to zero in 1998-00; finally, for the analyses of the 2007-09 recession we define the recession indicator as one for the years 2008-09 and zero for the years 2005-07.

We define small firms as firms with at most 99 employees and large firms with $100+$ employees. Later in the analyses we have a more granular definition of firm size. Information about the size of the employer is reported by the Current Population Survey respondents and refers to the main employer in the year prior to the survey. The small-firm indicator in equation (1) accounts for the fact that during non-recession times the transition from employment to unemployment may differ by firm size. To capture the differences in transition to unemployment by firm size during a recession, we interact small-firm indicator with a recession indicator. This is the main variable of interest in our analyses.

The contribution of this paper is the analysis of transition from employment to unemployment for workers during an economic downturn by firm size and external financial dependence. We define external financial dependence as the proportion of capital expenditures financed with external funds and mark every industry as having either "high" or "low" dependence on external finance, as explained in the next section. The specification in equation (1), therefore, includes a full set of interaction terms between all the right-hand side variables and an indicator for being in an industry with high external financial dependence. For ease of illustration we represent the additional interaction terms in equation (1) by an upper index $d=\{$ low,high $\}$ in all the regression parameters.

Thus, $\hat{\rho}^{\text {low }}$ estimates the impact of a recession on transition from employment to unemployment among workers in small firms relative to workers in large firms in industries with low external financial dependence, whereas $\widehat{\rho}^{\text {high }}$ 
has the same interpretation for industries with high external financial dependence. Our main interest is in the difference between the two point estimates,

$$
\widehat{\rho}^{h i g h}-\widehat{\rho}^{\text {low }}
$$

The difference between the estimates exploits variation in unemployment propensity across three dimensions: time (before and after the recession), firm size (small and large), and external financial dependence (high and low). The third dimension is especially useful because it helps isolate factors that have a differential impact on unemployment by firm size. It is possible, for example, that the reduction in the demand for goods and services during the recession fell disproportionately more on small firms and therefore affected their unemployment level. The estimate in (2) differences-out this potential effect as long as the reduction in the demand is not differential by firms' external financial dependence.

We estimate equation (1) using Ordinary Least Squares instead of Probit or Logit because of concerns of bias of nonlinear estimates with fixed effects. ${ }^{6}$ When assessing the statistical significance of the difference between $\widehat{\rho}^{\text {high }}$ and $\widehat{\rho}^{\text {low }}$, we cluster the standard errors by state and industry using the procedures in Liang and Zeger (1986) to adjust for potential group structure of the error term. ${ }^{7}$

\subsection{Data}

The unemployment status of workers is obtained from the Current Population Survey (CPS). The CPS is a monthly survey of about 50,000 households conducted by the Bureau of the Census for the Bureau of Labor Statistics. The survey represents the civilian population in the United States and is the official

\footnotetext{
${ }^{6}$ We have state-industry fixed effects separately for small and large firms, resulting in more than 5,500 fixed effects. Nonlinear estimates using Probit or Logit with this number of fixed effects may lead to biased estimates. In a specification with significantly less fixed effects we obtained essentially identical results using Ordinary Least Squares, Probit, and Logit.

${ }^{7}$ See Moulton (1986) and Bertrand, Duflo, and Mullainathan (2004) for further discussion about biases of standard errors with grouped data.
} 
source of U.S. unemployment statistics. In this paper we use the Annual Demographic Supplements to the CPS which are conducted every March. The March surveys are especially useful because they include information about the size of each individual's main employer in the year prior to the survey and her industry of occupation. Firm size is important because it helps us to categorize workers into small and large firms in terms the number of employees in the firm. Similarly, industry information is necessary because it helps us to assign measures of external financial dependence at the industry level based on separate calculation using Compustat firms.

The March CPS files are also very useful because they include characteristics of respondents, allowing us to control for these characteristics in the regression analyses. These demographics include age, gender, ethnicity, years of completed education, and state of residence. Finally, the CPS is a representative sample of the population. Each respondent in the CPS has a sampling weight which corresponds to her representation in the overall population. In all of our analyses we use the sampling weights provided by the CPS, thus recovering the representativeness of the sample. We include in the CPS sample all adult civilians aged $16+$ in the year prior the survey (the year of employment) who work for wages and salary in the private sector. We only exclude respondents whose main industry of occupation is in the financial sector or agriculture.

Information on the external financial dependence of the different industrial sectors is based on data from Compustat. To construct this measure, which was originally proposed by Rajan and Zingales (1998), we follow the procedures described in Cetorelli and Strahan (2006) and define external financial dependence as the proportion of capital expenditures financed with external funds. We use Compustat firms between the years 1980 and 1996 and separate them based on the number of years they have been on Compustat. We only use firms that have been on Compustat for at least 10 years. The reason for this choice is to capture firms' demand for credit and not the amount of credit supplied to them. It has been widely documented that young firms are financially constrained and their debt is likely to be determined by the amount of 
credit offered to them and not by the optimal equity-to-debt ratio (see e.g., Fazzari et al 1988).

We sum across all years each firm's total capital expenditures minus cash flows from operations and then divide it by total capital expenditures. A negative value of the resulting ratio indicates that firms have free cash, whereas a positive value indicates that firms must issue debt or equity to finance investments. Next, we aggregate the firm-level ratios of external financial dependence using the median value for all firms in each two-digit Standard Industrial Classification (SIC) category. Finally, we match the two-digit SIC categories to the industrial categories in the CPS. The mapping between Compustat and CPS industrial categories is in the Appendix Table 4.

Table 2 in the Appendix reports measures of external financial dependence for each of the 60 industrial sectors in our sample. Following Rajan and Zingales (1998), we argue there is a technological reason why some industries depend more on external finance than others. For example, industries may differ in the scale of the initial project, the gestation period, the cash harvest period, and the requirement for continuing investment. These technological factors determine the demand for external financing. It implies that, ceteris paribus, industries such as pipelines, metal mining, and home furniture - which require a lot of external funding - should be more affected by a credit supply shock than industries like leather and leather products, insurance carriers, and forestry.

We also calculate industries' financial dependence using the 1998 Survey of Small Business Finance (SSBF). The survey covers a sample of 3,561 small firms with fewer than 500 employees. The SSBF measure of financial dependence captures bank dependence more accurately than the measure based on Compustat because it is based on small firms which primarily use bank loans. However, SSBF-based measure of bank dependence mixes demand for credit and supply of credit because it is based on a survey of small firms. Nevertheless, we find it useful to use an additional measure of dependence on bank financing as a robustness check.

For each firm in the SSBF we calculate the share of assets financed with 
debt from financial institutions. Debt includes loans, capital leases and lines of credit (limit), as well as personal mortgages. ${ }^{8}$ Bank dependence in each two-digit SIC category is equal to the median value of firms' share of assets financed with debt. Bank dependence is constructed for all industrial sectors in the SSBF and then matched to the industrial categories in the CPS.

Ideally, we would like to analyze changes in hiring and layoffs instead of looking only at the transition from employment to unemployment. Unfortunately, except for the Current Population Survey we were not able to find data that include both firm size and detailed industry information. The Business Employment Dynamics (BED) which contains information on job gains and losses for new/existing/closing establishments has information either by firm size or by industry, but not both. The Job Openings and Labor Turnover Survey (JOLTS) - which has information on job openings, hires, and separations - does not contain information on firm size. In the Business Dynamics Statistics (BDS) all the industries are collapsed into eight sectors. This aggregation is not granular enough to capture cross-industry heterogeneity in external financial dependence.

The analysis of unemployment in the Current Population Survey by firm size and dependence on external finance is subject to limitations. Each worker's firm size is available in the year prior to the survey only if she was employed at least for some time in that year. Thus, firm size information is not available for individuals who were unemployed for the entire year prior to the survey. This implies that long term unemployment spells are not captured in our calculations, which may underestimate the role of financing constraints.

Because we are estimating transition to unemployment, we are concerned about not capturing individuals who were unemployed in the previous year but are currently employed. The fraction of such individuals is not large, however, and does not affect our main results. We show this by assuming two extreme cases: first, we assigned all such workers to small firms, and second, to large

\footnotetext{
${ }^{8}$ Mortgages include both commercial and residential mortgages if funds were used for business purposes. We use the limits on the lines of credit to better capture the supply of credit to those businesses. The results are robust to alternative definitions that exclude mortgages from debt and use the balance on the lines of credit instead of the limits.
} 
firms. Making these two assumptions does not change our main findings.

Similarly, we are not capturing short term unemployment spells. This includes workers who switched jobs during the previous year, stayed unemployed while looking for a job, and were employed during the Survey. We are underestimating our main findings if such switching occurs primarily among smaller firms or overestimating if it happens primarily among larger firms. Figuring out the potential bias from not capturing short term unemployment is complicated because workers may also switch from small to large firms and vice versa.

Given these data limitations in the Current Population Survey and the other job data mentioned above, we supplement the analysis of transition to unemployment by looking at the impact of the Great Recession on the number of establishments, differentially by firm size and external financial dependence. The establishment analysis helps provide a more complete picture to better evaluate the aggregate implication of our main findings.

We use information on the number of establishments from the County Business Patterns (CBP), which is an annual count of establishments at the county level. Importantly, the CBP counts establishments by firm size and industry (3-digit NAICS). We sum the total number of establishments in a state-yearindustry separately for small and large firms and divide the total number of establishments by the state population. We use the natural logarithm of the number of establishments per capita as the left-hand side variable in a specification similar to equation (1). As in the CPS, we define small firms as firms with at most 99 employees and assign measures of external financial dependence to the industrial sectors in the CBP using figures from Compustat. The mapping between the industrial sectors in these two data is in the Appendix Table 3. 


\section{Results}

\subsection{Descriptive Statistics}

Table 1 reports mean characteristics of mature Compustat firms by the median external financial dependence (EFD) of their industry. Mature firms are firms that have been on Compustat for at least 10 years and are generally thought to be financially unconstrained. This implies that these firms should be able to undertake all profitable investment opportunities regardless of access to external financing. The table shows that growth of assets, capital expenditures, and sales for firms in low EFD industries is somewhat larger than firms with high EFD during the period 1980-1996. For example, the average real growth rate of assets of low EFD firms over the period 1980-1996 is $4.5 \%$ versus $1.9 \%$ for high EFD firms. However, the difference in growth rates of assets between the two groups of firms is statistically insignificant (column 3). The differences in growth rates of capital expenditures and sales between high and low EFD industries are insignificant as well. These figures suggest that the greater demand for external finance does not seem to reflect greater growth or investment opportunities. Instead, external finance reflects differences in financing needs mainly due to industry level technological reasons as was initially argued by Rajan and Zingales (1998).

Table 2 reports mean characteristics of workers by firm size and external financial dependence. We compare workers' age, gender, ethnicity, and years of completed education across small and large firms, separately for industries with high and low external financial dependence based on respondents to the 2005 March Current Population Survey. We find that small firms in both low and high EFD industries have slightly older workers and more whites. In industries with high external financial dependence, small firms have slightly more high-school drop-outs (4 percentage point difference). The gender composition across small and large firms is statistically identical.

The important result emerging from Table 2 is that differences in workers' characteristics between small and large firms are similar in industries with low and high external financial dependence. This is illustrated in column (7). 
For example, there is a 2.15 and 1.25 age difference between workers in small and large firms in low and high EFD industries, respectively. However, 2.15 and 1.25 are not statistically different from each other. This is also true for workers' gender, ethnicity, and years of completed education. The "balancing" of workers' characteristics across firm size and external financial dependence is important for our analyses of transition to unemployment. It helps to rule out the possibility that workers in small firms in industries with high external financial dependence are more likely to become unemployed because they have different characteristics.

\subsection{Main Results}

Our empirical strategy is to emphasize the differential impact of the Great Recession on the probability of transition to unemployment using the variation in firm size and financing needs. We illustrate this strategy in Table 3 using the specification in equation (1).

All estimates in Table 3 are from a single regression. For ease of illustration we present the results as follows: The columns of the table are divided by workers' firm size and external financial dependence (EFD) of their industry; the rows show the differences between the columns. Small firms are firms with 1-99 employees, whereas large firms have at least 100 employees. Industries with low external financial dependence are industries with below median EFD.

The first two columns indicate an almost identical increase of 2.0 and 2.1 percentage points in unemployment propensity among workers in small and large firms in industries with low EFD. The next two columns, on the other hand, show that the recession has a more pronounced impact on the probability of becoming unemployed for workers in high EFD industries. In these industries, the unemployment likelihood among workers of small firms increased by 3.2 percentage points compared to 2.1 in large firms. That is a difference of 1.1 percentage points. The second row of the table shows that this difference is statistically significant at $1 \%$ confidence level.

The third row of Table 3 exploits the variation across the dimensions of 
firm size and external financial dependence by taking the difference between the two differences in the second row. In the notation of equation (2) this difference is,

$$
\widehat{\rho}^{\text {high }}-\widehat{\rho}^{\text {low }}=(.032-.021)-(.020-.021)=.012
$$

The point estimate of .012 means that the relative (small vs large) impact of the recession on unemployment propensity is 1.2 percentage points larger in industries with high financing needs. This difference is statistically significant and economically large. During the Great Recession the unemployment rate has doubled from 5.0 percent in December 2007 to 10.0 percent in December 2009 (Bureau of Labor Statistics). Relative to this rise, a 1.2 percentage point change corresponds to a quarter of the change in unemployment rate during the recession.

Our interpretation of the findings is that financing constraints played an important role in explaining changes in unemployment during the Great Recession. An alternative interpretation, however, is that the recession was especially harmful for the demand for goods and services produced by small businesses. And perhaps the drop in demand was especially steep for small businesses in industries with high external financial dependence.

We explore this possibility across two dimensions. First, we account for industry-state fixed effects, thus estimating the changes in unemployment in small versus large firms within the same industry and state. The identifying assumption here is that changes in the demand were not differential by firm size within an industry in any given state.

Second, we exclude the construction sector from the analysis realizing that the construction sector has especially suffered during the recession. Table 1 in the Appendix shows the results from this exercise. The construction sector has external financial dependence above the median and thus the results in the first two columns of Table 1 in the Appendix are identical to the results in Table 3. In high EFD industries, changes in unemployment are smaller for workers in both small and large firms once the construction workers are excluded. 
Nevertheless, the differential impact of the recession by firm size is significant $(.0245-.0176=.007)$ both statistically and economically. The difference between high and low external financial dependence $(.007-(-.001)=.008)$ is significant as well, indicating that our core findings hold when we exclude the construction sector.

\subsection{Monotonicity Analysis}

So far we have split workers into two buckets of firm size (small and large) and two buckets of external financial dependence (high and low). In this section we break both firm size and external financial dependence into three categories. If changes in unemployment are driven by changes in the supply of credit, we expect the probability of unemployment to increase monotonically with external financial dependence and to decline monotonically with respect to firm size.

To test the monotonicity of our findings with respect to firm size and external financial dependence (EFD), we plot the changes in workers' unemployment propensity in 2008-2009 relative to 2005-2007 in Figure 1. First, in panel (a) and (b), instead of separating firms into only two categories, we split the sample into three equal-sized buckets based on the distribution of external financial dependence. Workers in the lowest 33 percentiles of the EFD distribution belong to the "low" EFD bucket, whereas workers in the top 33 percentiles fall into the "high" EFD bucket. Workers between the 34th and the 66th percentiles are in the "medium" category. As before, we separate firms by two categories of firm size: 1-99 versus $100+$ employees. The bars in Figure 1 represent point estimates of $\delta$ from the following specification:

$$
y_{i j s t}=\alpha_{j s}+\mathbf{x}_{i j s t}^{\prime} \boldsymbol{\theta}+\text { drecession }_{t}+u_{i j s t}
$$

where, as before, $y_{i j s t}$ is an indicator that equals to one if person $i$ - whose main industry of occupation in the previous year was $j$ and who currently resides in state $s$ - switched from employment to unemployment between the years $t-1$ and $t . \alpha_{j s}$ are industry-state fixed effects and the vector of characteristics $\mathbf{x}$ 
controls for workers' observable differences in age, gender, ethnicity, and years of completed education. Finally, recession takes the value of unity in the years 2008-2009 and equals zero in the years 2005-2007. We estimate equation (3) using Ordinary Least Squares. We use sampling weights provided by the CPS to ensure representativeness of our sample.

We estimate $\delta$ in equation (3) six times for each category of firm size and for the three groups of external financial dependence. The results, shown in panels (a) and (b) of Figure 1, show that during the recession the unemployment propensity is changing monotonically with the degree of external financial dependence but only for small firms. In particular, we find that workers of small firms in low EFD industries were 2.1 percentage points more likely to become unemployed compared to 2.6 percentage points in the medium EFD and 3.6 percentage points in the high EFD group. However, for large firms, there is no evidence for a monotonic relationship between the likelihood of becoming unemployed and external financial dependence.

Next, we test the monotonicity of our findings with respect to firm size. Specifically, we separate firms into three categories of size based on the number of employees: 1-99, 100-499, and 500+, and separate industries by the median external financial dependence. So, this time we estimate equation (3) separately by the two categories of external financial dependence and three categories of firm size.

The results are presented in panels (c) and (d) of Figure 1. The figures show a clear-cut monotonic relationship between the propensity of becoming unemployed and firm size in high EFD industries. The largest changes in unemployment are for workers of the smallest firms (1-99 employees), whereas the smallest changes are for those in the largest firms $(500+$ employees). In particular, a high EFD industry worker in a firm with 1-99 employees is 3.2 percentage points more likely to become unemployed during the crisis, compared to 2.9 percentage points for those working in firms with 100-499 employees, and 1.9 percentage points in firms with $500+$ employees. In industries with low external financial dependence, on the other hand, there is no relationship between firm size and the likelihood of becoming unemployed 
during the recession.

The monotonicity analyses provide further evidence for the channels that drive the transitions to unemployment during the 2008-2009 financial crisis. We find a monotonic relationship between firm size and changes in unemployment propensity. Importantly, this relationship holds only for industries with high external financial dependence. From a different angle, we find a monotonic relationship between external financial dependence and changes in unemployment. Strikingly, this relationship holds only for smaller firms.

\section{Robustness Tests}

\subsection{Other Recessions}

So far our findings indicate that the financial crisis of 2007-09 is especially harmful for small firms in industries with high financing needs. Our interpretation is that changes in unemployment in these firms are driven by changes in the supply of credit. To provide further evidence for this hypothesis we repeat our empirical exercise for the 2001 recession and for the Savings and Loan (S\&L) crisis that led to the 1990-91 recession.

The 2001 recession was triggered by the bursting of the bubble in the technological sector and did not originate in banks' balance sheets. The 2001 recession, therefore, serves as a "placebo" test: if changes in unemployment

in small, financially constrained firms are driven by changes in the supply of credit, then we should find no differential impact of the 2001 recession on unemployment by firm size and external financial dependence.

The S\&L crisis, on the other hand, originated in the banking sector and was related to problems in the real estate. The resulting credit crunch and the recession in 1990-91 provide an ideal scenario to test the robustness of our findings. If credit supply contraction is important in driving transition to unemployment for bank dependent firms, then our estimates around the 199091 recession should be similar to the estimates around the 2007-09 recession.

In addition, the 1990-91 recession was characterized by a strong geograph- 
ical component, with New England being the most affected region (Peek and Rosengren 1994). We exploit this regional variation by estimating transition to unemployment separately for New England. We expect small, financially constrained firms in New England to be especially affected by the 1990-91 recession.

We start with the 2001 recession in Table 4. The specification here is identical to Table 3, except that the recession indicator now takes the value of unity in the years 2001-2002 and takes the value of zero in the years 1998-2000. We find that in industries with low external financial dependence, workers are 0.6 percentage points more likely to become unemployed if they were in small firms and 1.2 percentage points if they work in large firms. The difference between the two estimates is statistically significant. In industries with high external financial dependence, the probability of unemployment increased by 0.6 and 0.8 percentage points for small and large firms, respectively. This difference is statistically insignificant. More importantly, the difference of the differences $(-.003-(-.007)=.004)$ is insignificant as well, indicating that financing constraints become insignificant in explaining the unemployment patterns of small or large firms during the 2001 recession.

In Table 5 we analyze the results for the 1990-91 recession. The recession indicator in this table takes the value of unity in the years 1991-1992 and takes the value of zero in the years 1988-1990. Similarly to the analysis of the Great Recession, workers in small firms in industries with high financing needs are primarily affected by the 1990-91 recession. The difference between small and large firms in high EFD industries (1.3 percentage points) is statistically different from the same difference in low EFD industries $(-0.4$ percentage points) and is also economically large.

In Table 6 we turn to the regional analysis of the 1990-91 recession. The specifications in this table are identical to Table 5, except the separation of the results by regions. In panel A we report the results only for New England and in panel $\mathrm{B}$ for the other regions. Consistent with the fact that the credit crunch was more severe in New England, workers in small firms in industries with high financing needs in New England have the steepest rise in unemploy- 
ment during the 1990-91 recession. This increase was larger than for workers in corresponding firms in regions outside of New England and larger than in industries with low external financial dependence. These results further reinforce the credit supply channel.

We graphically illustrate our findings through the various recessions in Figure 2. We plot the year-by-year proportion of workers who switched from employment to unemployment between the years $t$ and $t-1$ by firm size and external financial dependence using the March Current Population Surveys from 1988 to 2011. The left plot is for industries with low EFD and the right plot is for high EFD industries. The solid lines represent workers in small firms (1-99 employees), while the dashed lines are for workers in large firms (100+ employees).

This figure depicts the results we are capturing in the regressions. Clearly, transition to unemployment increases in recession periods. However, there are remarkable differences across firm size and external financial dependence. For industries with low financing needs, the unemployment trends for workers in small and large firms move very closely. In industries with high financing needs, on the other hand, the transition to unemployment during recessions increases much more for smaller firms.

\subsection{Bank Dependence}

So far our analyses relied on measures of external financial dependence based on mature Compustat firms. As a robustness check we construct an alternative measure of financing needs. We follow the work of Cetorelli and Strahan (2006) and construct measures of bank dependence using the 1998 Survey of Small Business Finance (SSBF). The SSBF measure of financial dependence captures bank dependence more accurately than the measure based on Compustat because it is based on small firms which primarily use bank loans. However, SSBF-based measure of bank dependence mixes demand for credit and supply of credit because it is based on a survey of small firms. Nevertheless, we find it useful to use an additional measure of dependence on bank 
financing as a robustness check.

For each firm we calculate the share of assets financed with debt from financial institutions, as explained in Section 2.2. Bank dependence in each two-digit SIC category is equal to the median value of firms' share of assets financed with debt. It is constructed for all industrial sectors and not just manufacturing. We split the industries by the median dependence on banks. Industries with below median bank dependence have low bank dependence, whereas industries with above median bank dependence have high bank dependence.

The results in Table 7 are very similar to the results in Table 3 where we used Compustat-based measure of financing needs. As before, we find no differential impact of the Great Recession on unemployment by firm size in industries with low bank dependence. The difference is equal to 0.3 percentage points $(.020-.017)$ which is not statistically different from zero. In industries with high bank dependence, on the other hand, the probability of becoming unemployed rises by 1.2 percentage points $(.039-.028)$ more for workers in small firms. The difference of the differences $(.012-.003)$ is statistically significant at the $10 \%$ level and is very similar in magnitude to corresponding difference in Table 3. Overall, the results in Table 7 show that our core findings are robust to the measure of financial dependence.

\subsection{Number of Establishments}

One of the limitations of our analyses in this paper is that we focus only on the transition of workers from employment to unemployment, thus missing other important margins. The reason for this limitation is data availablity as we describe in detail in the Data Section. Looking only at one margin becomes especially binding when thinking about policies to help the labor market where unemployment rate remains at a very high level.

In order to obtain a more complete picture, we complement our core findings by analyzing changes in the number of establishments from the County 
Business Patterns. ${ }^{9}$ The idea is to use the change in the number of establishments as measure that combines changes in both employment and unemployment. We estimate a model similar to our baseline specification in equation (1) with the exception that the dependent variable is the natural logarithm of the number of establishments per capita in a given industry, state and year. Another exception is that we, of course, do not control for the vector of workers' characteristics, $\mathbf{x}$, as we analyze establishments and not workers.

Table 8 shows that the number of establishments contracted during the Great Recession. We also find that this contraction was steeper among firms in industries with high external financial dependence, especially for smaller firms. Specifically, in these industries the number of establishments among large firms dropped by 4.0 percent compared to 5.2 percent among small firms. The contraction was smaller in industries with low financing needs and very similar between large and small firms (3.6 and 3.5 percent, respectively). The difference of the small-large differences $(-.012-.001)$ is statistically significant at the $5 \%$ level.

Using the average number of establishments per capita before the recession and the average number of employees in a small establishment, a back of the envelope calculation suggests that credit constraints may account for a decrease of about 76,200 establishments which corresponds to about 700,000 jobs. This number is very similar to the one implied by our main findings in Table 3. In particular, according to our initial estimates, financial constraints of small firms contributed about 0.55 percentage points to the overall unemployment rate, which correspond to about 750,000 jobs. Although both of these calculations are based on a partial equilibrium framework and miss any associated general equilibrium effects, they still provide a useful benchmark for highlighting the importance of financial constraints from an aggregate employment perspective.

\footnotetext{
${ }^{9}$ Ideally, we would like to study the total changes in employment. See Section 2.2 for a discussion of the data limitations that prevent us from doing such an analysis.
} 


\section{Concluding Remarks}

This paper shows that financing constraints of small firms are important drivers of unemployment dynamics around the Great Recession. In particular, workers in small firms in industries with high external financial dependence were more likely to become unemployed during the financial crisis than workers in large firms in the same industries. On the other hand, we do not find significant differences in unemployment between workers in small and large firms in sectors with low external financial dependence. These results indicate that the reduction in bank lending to small and financially constrained firms during the Great Recession is associated with increased layoffs of workers.

To provide additional assurance that we are capturing credit supply shocks, we also examine the 1990-91 and the 2001 recessions in the U.S. For the 199091 recession, we find very similar results to the Great Recession, namely larger changes in unemployment among workers in small firms in industrties with high external financial dependence. Moreover, we find especially significant impact on workers in New England where banks were disproportionally affected by the Savings and Loan crisis. The 2001 recession, on the other hand, had no differential impact on unemployment by firm size and external financial dependence. This is in line with our prior because the 2001 recession was concentrated in the technological sector, and unlike the 1990-91 recession banks were largely unaffected.

This paper indicates that financing constraints of small firms may be significantly affecting the labor markets in the U.S. The resulting policy implications are especially important. We suggest that policies aimed at making credit available to small firms, such as the $\$ 30$ billion Small Business Bill or the loans guaranteed by the Small Business Administration, would help stabilize the labor markets and economic activity in the United States. 


\section{References}

Almeida, Heitor, Murillo Campello, Bruno Laranjeira, and Scott Weisbenner. 2010. "Corporate Debt Maturity and the Real Effects of the Panic of August 2007." Unpublished.

Bascim Erdem, Yusuf Soner Baskaya, and Mustafa Kilinc. 2011. "Financial Shocks and Industrial Employment." Unpublished.

Benmelech, Efraim, Nittai K. Bergman, and Amit Seru. 2011. "Financing Labor." National Bureau of Economic Research Working Paper 17144.

Berger, Alan N., Leora F. Klapper, and Gregory F. Udell. 2001. "The Ability of Banks to Lend to Informationally Opaque Small Businesses." Journal of Banking and Finance, 25(12): 2127-67.

Bernanke, Ben S. 1983. "Nonmonetary Effects of the Financial Crisis in the Propagation of the Great Depression." American Economic Review, 73(3): 257-76.

Bernanke, Ben S., and Mark Gertler. 1989. "Agency Costs, Net Worth, and Business Fluctuations." American Economic Review, 79(1): 14-31.

Bertrand, Marianne, Esther Duflo, and Sendhil Mullainathan. 2004. "How Much Should We Trust Differences-in-Differences Estimates?" Quarterly Journal of Economics, 119(1): 249-75.

Braun, Matias, and Borja Larrain. 2005. "Finance and the Business Cycle: International, Inter-Industry Evidence." Journal of Finance, 60(3): 10971128.

Campello, Murillo, John R. Graham, and Campbell R. Harvey. 2010. "The Real Effects of Financial Constraints: Evidence from a Financial Crisis." Journal of Financial Economics, 97(3): 470-87.

Cetorelli, Nicola, and Philip E. Strahan. 2006. "Finance as a Barrier to Entry: Bank Competition and Industry Structure in Local U.S. Markets." Journal of Finance, LXI(1): 437-61.

Cole, Rebel A., John D. Wolken, and R. Louise Woodburn. 1996. "Bank and Nonbank Competition for Small Business Credit: Evidence from the 1987 and 1993 National Surveys of Small Business Finances." Fed. Res. Bull., 82: 983-95. 
Dell'Ariccia, Giovanni, Enrica Detragiache, and Raghuram Rajan. 2008. "The Real Effect of Banking Crises." Journal of Financial Intermediation, 17(1): 89-112.

Duchin, Ran, Oguzhan Ozbas, and Berk A. Sensoy. 2010. "Costly External Finance, Corporate Investment, and the Subprime Mortgage Credit Crisis." Journal of Financial Economics, 97(3): 418-35.

Fazzari, Steven M., R. Glenn Hubbard, and Bruce C. Peterson. 1988. "Financing Constraints and Corporate Investment." Brookings Papers on Economic Activity: 141-206.

Gertler, Mark, and Simon Gilchrist. 1994. "Monetary Policy, Business Cycles, and the Behavior of Small Manufacturing Firms." Quarterly Journal of Economics, 109(2): 309-40.

Gertler, Mark L., and R. Glenn Hubbard. 1988. "Financial Factors in Business Fluctuations." National Bureau of Economic Research Working Paper 2758.

Gozzi, Juan Carlos, and Martin Goetz. 2010. "Liquidity Shocks, Local Banks, and Economic Activity: Evidence from the 2007-2009 Crisis." Unpublished.

Guiso, Luigi, Paula Sapienza, and Luigi Zingales. 2004. "Does Local Financial Development Matter?" Quarterly Journal of Economics, 119(3): 929-69.

Haltiwanger, John, Ron Jarmin, and Javier Miranda. 2010. "Who Creates Jobs?: Small vs. Large vs. Young." National Bureau of Economic Research Working Paper 16300.

Holstrom, Bengt, and Jean Tirole. 1997. "Financial Intermediation, Loanable Funds, and the Real Sector." Quarterly Journal of Economics, 112(3): 663-91.

Hoshi, Takeo, Anil Kashyap, and David Scharfstein. 1991. "Corporate Structure, Liquidity, and Investment: Evidence from Japanese Industrial Groups." Quarterly Journal of Economics, 106(1): 33-60.

Huang, Haifang, and Eric Stephens. 2011. "From Housing Bust to Credit Crunch: Evidence from Small Business Loans." Unpublished. 
Ivashina, Victoria, and David Scharfstein. 2010. "Bank Lending During the Financial Crisis of 2008." Journal of Financial Economics, 97(3): 319-38.

Jayaratne, Jith, and Philip E. Strahan. 1996. "The Finance-Growth Nexus: Evidence from Bank Branch Deregulation." Quarterly Journal of Economics, 111(3): 639-70.

Kashyap, Anil K., Owen A. Lamont, and Jeremy C. Stein. 1994. "Credit Conditions and the Cyclical Behavior of Inventories." Quarterly Journal of Economics, 109(3): 565-92.

King, Robert G., and Ross Levine. 1993. "Finance and Growth: Schumpeter Might Be Right." Quarterly of Journal Economics, 108(3): 717-37.

Kroszner, Randall S., Luc Laeven, and Daniele Klingebiel. 2007. "Banking Crises, Financial Dependence, and Growth." Journal of Financial Economics, 84(1): 187-228.

Levine, Ross, and Sarah Zervos. 1998. "Stock Markets, Banks, and Economic Growth." American Economic Review, 88(3): 537-58.

Liang, Kung-Yee, and Scott L. Zeger. 1986. "Longitudinal Data Analysis Using Generalized Linear Models." Biometrika, 73(1): 13-22.

Moscarini, Giuseppe, and Fabien Postel-Vinay. 2009. "Large Employers are More Cyclically Sensitive." National Bureau of Economic Research Working Paper 14740.

Moulton, Brent R. 1986. "Random Group Effects and the Precision of Regression Estimates." Journal of Econometrics, 32(3): 385-97.

Neumark, David, Brandon Wall, and Junfu Zhang. 2011. "Do Small Businesses Create More Jobs? New Evidence for the United States from the National Establishment Time Series." Review of Economics and Statistics, 93(1): 16-29.

Nickell, Stephen, and Daphne Nicolitsas. 1999. "How Does Financial Pressure Affect Firms?" European Economic Review, 43(8): 1435-56.

Peek, Joe, and Eric S. Rosengren. 1994. "Bank Real Estate Lending and the New England Credit Crunch." Real Estate Economics, 22(1): 33-58. 
Peek, Joe, and Eric S. Rosengren. 2000. "Collateral Damage: Effects of the Japanese Bank Crisis on Real Activity in the United States." American Economic Review, 90(1): 30-45.

Petersen, Mitchell A., and Raghuram G. Rajan. 1994. "The Benefits of Lending Relationships: Evidence from Small Business Data." Journal of Finance, 49(1): 3-37.

Polivka, Anne E. 1996. "Data Watch: The Redesigned Current Population Survey." Journal of Economic Perspectives, 10(3): 169-180.

Rajan, Raghuram G., and Luigi Zingales. 1998. "Financial Dependence and Growth." American Economic Review, 88(3): 559-86.

Sharpe, Steven A. 1994. "Financial Market Imperfections, Firm Leverage, and the Cyclicality of Employment." American Economic Review, 84(4): 106074 .

Whited, Toni M. 1992. "Debt, Liquidity Constraints, and Corporate Investment: Evidence from Panel Data." Journal of Finance, 47(4): 1425-60. 
Figure 1 - Monotonicity by External Financial Dependence and Firm Size

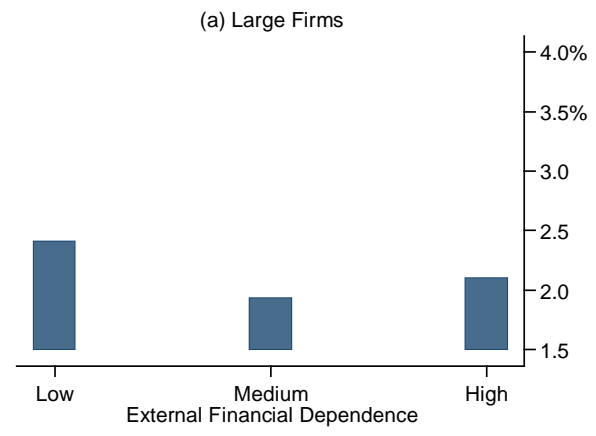

(c) Low External Financial Dependence

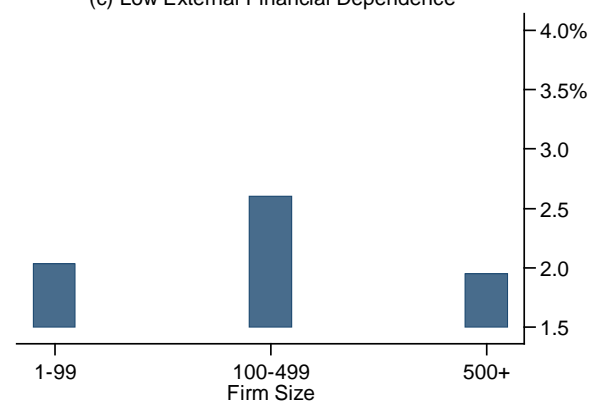

(b) Small Firms

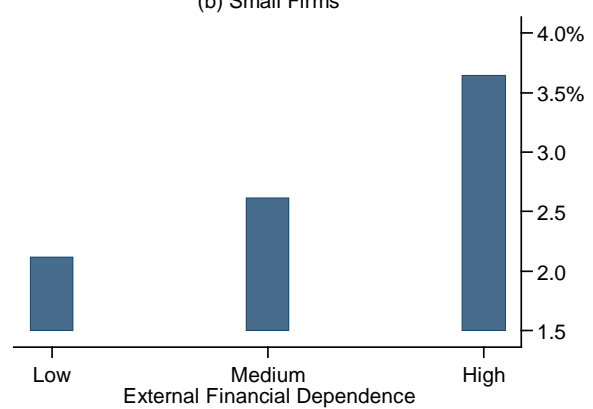

(d) High External Financial Dependence

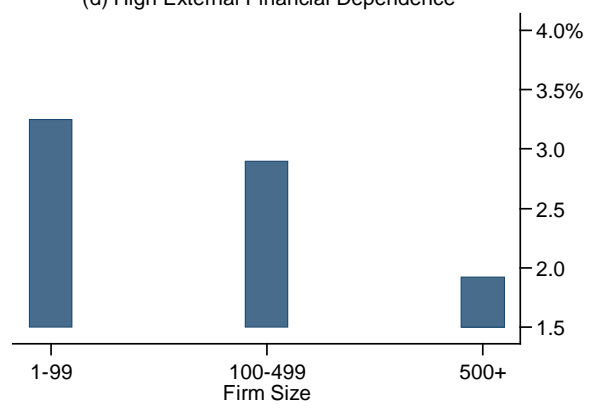

Note - The plots show changes in unemployment rate following the 2007-09 recession by external financial dependence and firm size. The upper plots are divided into three categories based on the distribution external financial dependence: below the $33^{\text {rd }}$ percentile, $34^{\text {th }}-66^{\text {th }}$ percentile, and $67^{\text {th }}$ percentile and above. Plot (a) includes firms with at least 100 employees, whereas plot (b) includes firms with at most 99 employees. The lower plots are divided into three categories of firm size based on the number of workers in the firm: 1-99, 100-499, and $500+$. Plot (c) includes industries with below median external financial dependence. Plot (d) includes industries with external financial dependence above the median. External financial dependence equals the proportion of capital expenditures financed with external funds. External financial dependence is calculated using mature Compustat firms for the period 1980-1996. The bars represent estimates from 12 separate OLS regression where the dependent variables is an indicator that equals to one if a person transitioned from employment to unemployment between years $t-1$ and $t$. Each regression controls for workers' characteristics and state-industry (2-digit SIC) fixed effects. Workers' characteristics include age, gender, ethnicity, and years of completed education (0-11 years, 12, 13-15, or 16). All estimates are weighted by sampling weights provided by the Current Population Survey. 
Figure 2 - Likelihood of Transition from Employment to Unemployment

Low External Financial Dependence

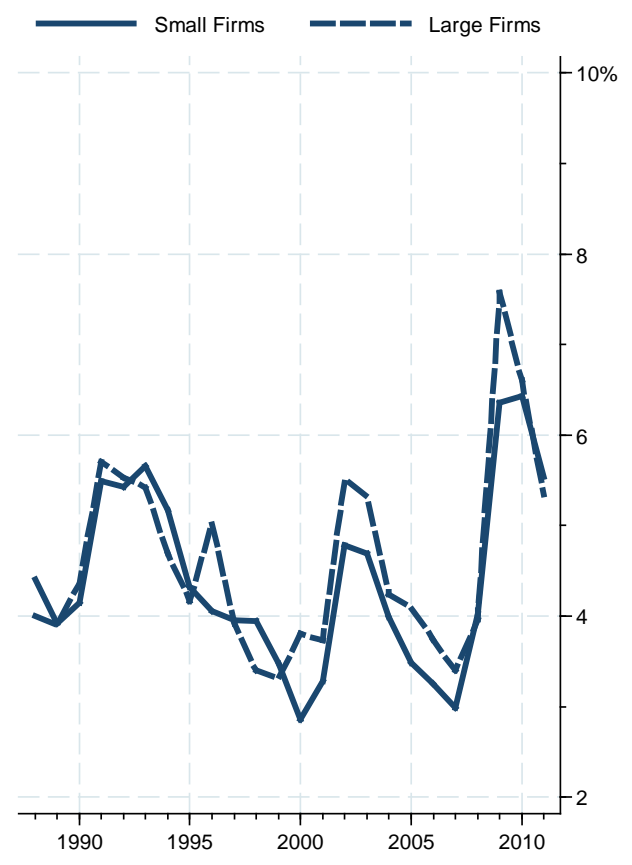

High External Financial Dependence

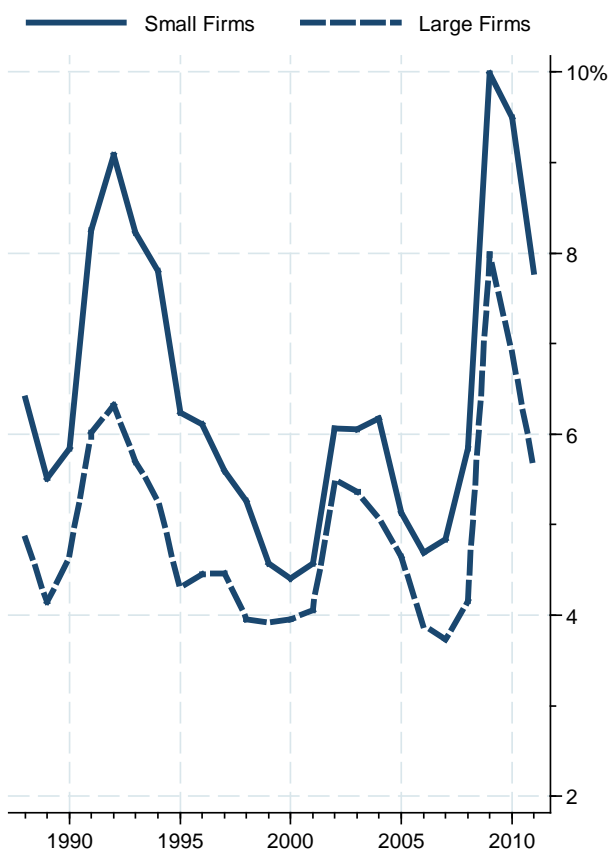

Note - The plots show year-by-year proportion of workers who switched from employment to unemployment between years $t$ and $t-1$ by firm size and external financial dependence. "Small" firms have at most 99 employees. External financial dependence equals the proportion of capital expenditures financed with external funds. A negative value (low external financial dependence) indicates that firms have free cash flow. A positive value indicates that firms must issue debt or equity to finance their investment. External financial dependence is calculated at 2-digit Standard Industrial Classification codes using mature Compustat firms for the period 19801996 using the procedures described in Cetorelli and Strahan [2006].

Source - March Current Population Surveys, 1988-2011. 
Table 1 - Characteristics of Firms by External Financial Dependence

\begin{tabular}{|c|c|c|c|}
\hline & \multicolumn{2}{|c|}{ External Financial Dependence } & \multirow[b]{2}{*}{$\begin{array}{c}\text { Difference } \\
\text { (3) }\end{array}$} \\
\hline & $\begin{array}{l}\text { Low } \\
(1)\end{array}$ & $\begin{array}{l}\text { High } \\
(2)\end{array}$ & \\
\hline Assets growth & .045 & .019 & $\begin{array}{l}-.026 \\
(.016)\end{array}$ \\
\hline Capital expenditures growth & .201 & .134 & $\begin{array}{l}-.067 \\
(.082)\end{array}$ \\
\hline Sales growth & .066 & .042 & $\begin{array}{l}-.024 \\
(.031)\end{array}$ \\
\hline $\begin{array}{l}\text { Note - The table reports characterist } \\
\text { industry. Column (3) reports the diffe } \\
\text { in parentheses. The results are bas } \\
\text { Mature firms are firms that have bee } \\
\text { capital expenditures, and sales are } \\
\text { rates over the period } 1980-1996 \text {. } \\
\text { expenditures financed with external } \\
\text { indicates that firms have free cash flo } \\
\text { to finance their investment. External } \\
\text { Classification codes using mature } \\
\text { described in Cetorelli and Strahan }\end{array}$ & $\begin{array}{l}\text { of Compustat } f \\
\text { ce between the } \\
\text { on } 4,847 \text { matu } \\
\text { Compustat for } \\
\text { ian values of } y \\
\text { rnal financial } \\
\text { nds. A negativ } \\
\text { A positive value } \\
\text { ncial dependen } \\
\text { pustat firms for }\end{array}$ & $\begin{array}{l}\text { Ial financial de } \\
\text { mns. Robust } \mathrm{s} \\
\text { t firms in the } \\
\text { ars. The grow } \\
\text { al (\$1997, CP } \\
\text { quals the pro } \\
\text { external finan } \\
\text { t firms must is } \\
\text { d at a 2-digit } \$ \\
980-1996 \text { usin }\end{array}$ & $\begin{array}{l}\text { endence of their } \\
\text { ndard errors are } \\
\text { ars } 1980-1996 . \\
\text { rates of assets, } \\
\text { djusted) growth } \\
\text { ojtion of capital } \\
\text { al dependence) } \\
\text { le debt or equity } \\
\text { indard Industrial } \\
\text { the procedures }\end{array}$ \\
\hline
\end{tabular}


Table 2 - Characteristics of Labor by Firm Size and External Financial Dependence

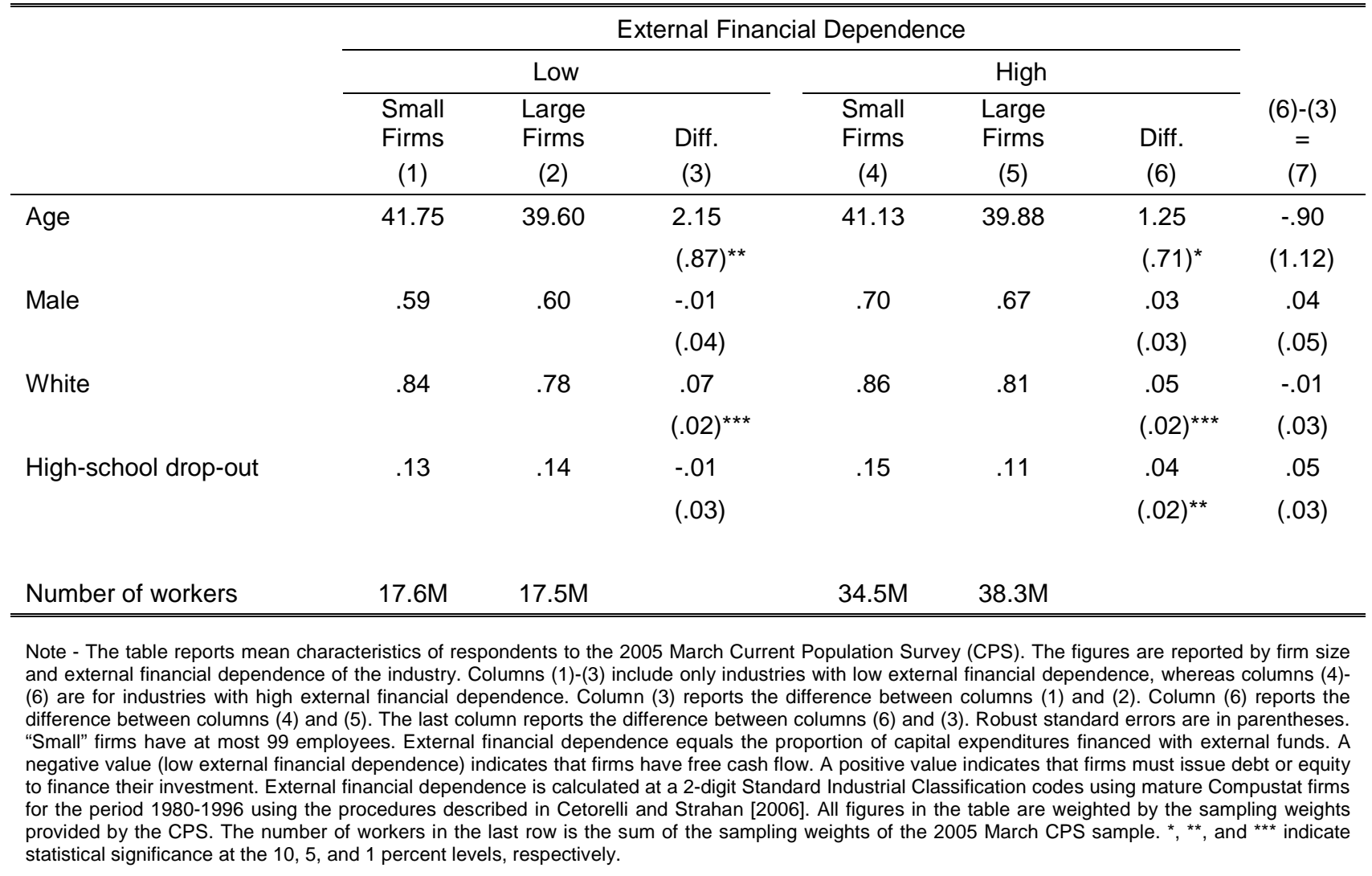


Table 3 - Transition to Unemployment following the December 2007 Recession

\begin{tabular}{|c|c|c|c|c|}
\hline & \multicolumn{4}{|c|}{ External Financial Dependence } \\
\hline & \multicolumn{2}{|c|}{ Low } & \multicolumn{2}{|c|}{ High } \\
\hline & $\begin{array}{c}\text { Small } \\
\text { Firms } \\
(1) \\
\end{array}$ & $\begin{array}{c}\text { Large } \\
\text { Firms } \\
(2)\end{array}$ & $\begin{array}{c}\text { Small } \\
\text { Firms } \\
(3) \\
\end{array}$ & $\begin{array}{c}\text { Large } \\
\text { Firms } \\
(4) \\
\end{array}$ \\
\hline Recession & $\begin{array}{l}.020 \\
(.002)^{\star \star \star}\end{array}$ & $\begin{array}{l}.021 \\
(.003)^{\star \star \star}\end{array}$ & $\begin{array}{l}.032 \\
(.003)^{\star \star \star}\end{array}$ & $\begin{array}{l}.021 \\
(.002)^{\star \star \star}\end{array}$ \\
\hline \multicolumn{5}{|l|}{ Differences: } \\
\hline $\begin{array}{l}\text { Small - Large } \\
(\text { Small - Large })^{\text {High }}-(\text { Small - Large })^{\text {Low }}\end{array}$ & $\begin{array}{r}- \\
\text { (. }\end{array}$ & 更 & 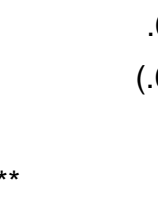 & )$^{\star \star \star}$ \\
\hline Observations & 61,572 & 61,860 & 118,824 & 131,621 \\
\hline $\begin{array}{l}\text { Note - The dependent variable is an indicator tha } \\
\text { between years } t-1 \text { and } t \text {. The table reports Ordina } \\
\text { controls for workers' characteristics and state-indu } \\
\text { ethnicity, and years of completed education (0-11 } \\
\text { industry (2-digit SIC) level and appear in parenthes } \\
\text { CPS. "Recession" equals to one in the years } 2008 \\
\text { employees. External financial dependence equals } \\
\text { value (low external financial dependence) indicates } \\
\text { debt or equity to finance their investment. External } \\
\text { codes using mature Compustat firms for the period } \\
\text { and }{ }^{* \star *} \text { indicate statistical significance at the } 5 \% \text { and }\end{array}$ & $\begin{array}{l}\text { quals to one if } \\
\text { Least Squares } \\
\text { y (2-digit SIC) } \\
\text { ars, 12, 13-15, } \\
\text { All estimates a } \\
\text { and equals to } \\
\text { proportion of ce } \\
\text { at firms have fre } \\
\text { ancial depender } \\
\text { 80-1996 using t } \\
\text { \% levels, respect }\end{array}$ & $\begin{array}{l}\text { erson transitio } \\
\text { mates. All estil } \\
\text { effects. Work } \\
\text { ). Standard er } \\
\text { eighted by prol } \\
\text { o in the years } \\
\text { expenditures } \\
\text { sh flow. A posi } \\
\text { s calculated at } \\
\text { rocedures des }\end{array}$ & $\begin{array}{l}\text { m employment } \\
\text { are from a sing } \\
\text { aracteristics inc } \\
\text { eadjusted for } \\
\text { sampling weigh } \\
\text { 7. "Small" firm } \\
\text { d with external } \\
\text { ue indicates th } \\
\text { Standard Indu } \\
\text { n Cetorelli and }\end{array}$ & $\begin{array}{l}\text { unemployment } \\
\text { egression that } \\
\text { age, gender, } \\
\text { ering at state- } \\
\text { rovided by the } \\
\text { ve at most } 99 \\
\text { ds. A negative } \\
\text { ms must issue } \\
\text { Classification } \\
\text { han [2006]. * }\end{array}$ \\
\hline
\end{tabular}


Table 4 - Transition to Unemployment following the March 2001 Recession

\begin{tabular}{|c|c|c|c|c|}
\hline & \multicolumn{4}{|c|}{ External Financial Dependence } \\
\hline & \multicolumn{2}{|c|}{ Low } & \multicolumn{2}{|c|}{ High } \\
\hline & $\begin{array}{c}\text { Small } \\
\text { Firms } \\
(1)\end{array}$ & $\begin{array}{c}\text { Large } \\
\text { Firms } \\
(2)\end{array}$ & $\begin{array}{c}\text { Small } \\
\text { Firms } \\
(3)\end{array}$ & $\begin{array}{c}\text { Large } \\
\text { Firms } \\
(4)\end{array}$ \\
\hline Recession & $\begin{array}{l}.006 \\
(.002)^{\star \star}\end{array}$ & $\begin{array}{l}.012 \\
(.002)^{\star \star \star}\end{array}$ & $\begin{array}{l}.006 \\
(.002)^{\star \star \star}\end{array}$ & $\begin{array}{l}.008 \\
(.002)^{\star \star \star}\end{array}$ \\
\hline \multicolumn{5}{|l|}{ Differences: } \\
\hline $\begin{array}{l}\text { Small - Large } \\
(\text { Small - Large })^{\text {High }}-(\text { Small - Large })^{\text {Low }}\end{array}$ & - & )$^{\star \star \star}$ & - & 2) \\
\hline Observations & 48,934 & 53,076 & 93,496 & 110,102 \\
\hline $\begin{array}{l}\text { Note - The dependent variable is an indicator that } \\
\text { between years } t-1 \text { and } t \text {. The table reports Ordina } \\
\text { controls for workers' characteristics and state-indu } \\
\text { ethnicity, and years of completed education (0-11 } \\
\text { industry (2-digit SIC) level and appear in parenthese } \\
\text { CPS. "Recession" equals to one in the years } 2001 \\
\text { employees. External financial dependence equals th } \\
\text { value (low external financial dependence) indicates } \\
\text { debt or equity to finance their investment. External } \\
\text { codes using mature Compustat firms for the period } \\
\text { and }{ }^{* * *} \text { indicate statistical significance at the } 5 \% \text { and }\end{array}$ & $\begin{array}{l}\text { quals to one if } \\
\text { Least Squares } \\
\text { (2-digit SIC) } \\
\text { rs, 12, 13-15, } \\
\text { All estimates a } \\
\text { and equals to } \\
\text { proportion of c } \\
\text { tirms have fre } \\
\text { ancial depende } \\
\text { Bo-1996 using } \\
\text { levels, respec }\end{array}$ & $\begin{array}{l}\text { erson transitio } \\
\text { nates. All esti } \\
\text { effects. Work } \\
\text { ). Standard er } \\
\text { eighted by prol } \\
\text { in the years } \\
\text { expenditures } \\
\text { sh flow. A posi } \\
\text { s calculated at } \\
\text { rocedures des }\end{array}$ & $\begin{array}{l}\text { employment } \\
\text { e from a sing } \\
\text { acteristics inc } \\
\text { adjusted for } \\
\text { ampling weigh } \\
\text { "Small" firms } \\
\text { with external } \\
\text { e indicates the } \\
\text { tandard Indu } \\
\text { Cetorelli and }\end{array}$ & $\begin{array}{l}\text { unemployment } \\
\text { egression that } \\
\text { age, gender, } \\
\text { ering at state- } \\
\text { rovided by the } \\
\text { ve at most } 99 \\
\text { ds. A negative } \\
\text { ms must issue } \\
\text { Classification } \\
\text { han [2006]. ** }\end{array}$ \\
\hline
\end{tabular}


Table 5 - Transition to Unemployment following the July 1990 Recession

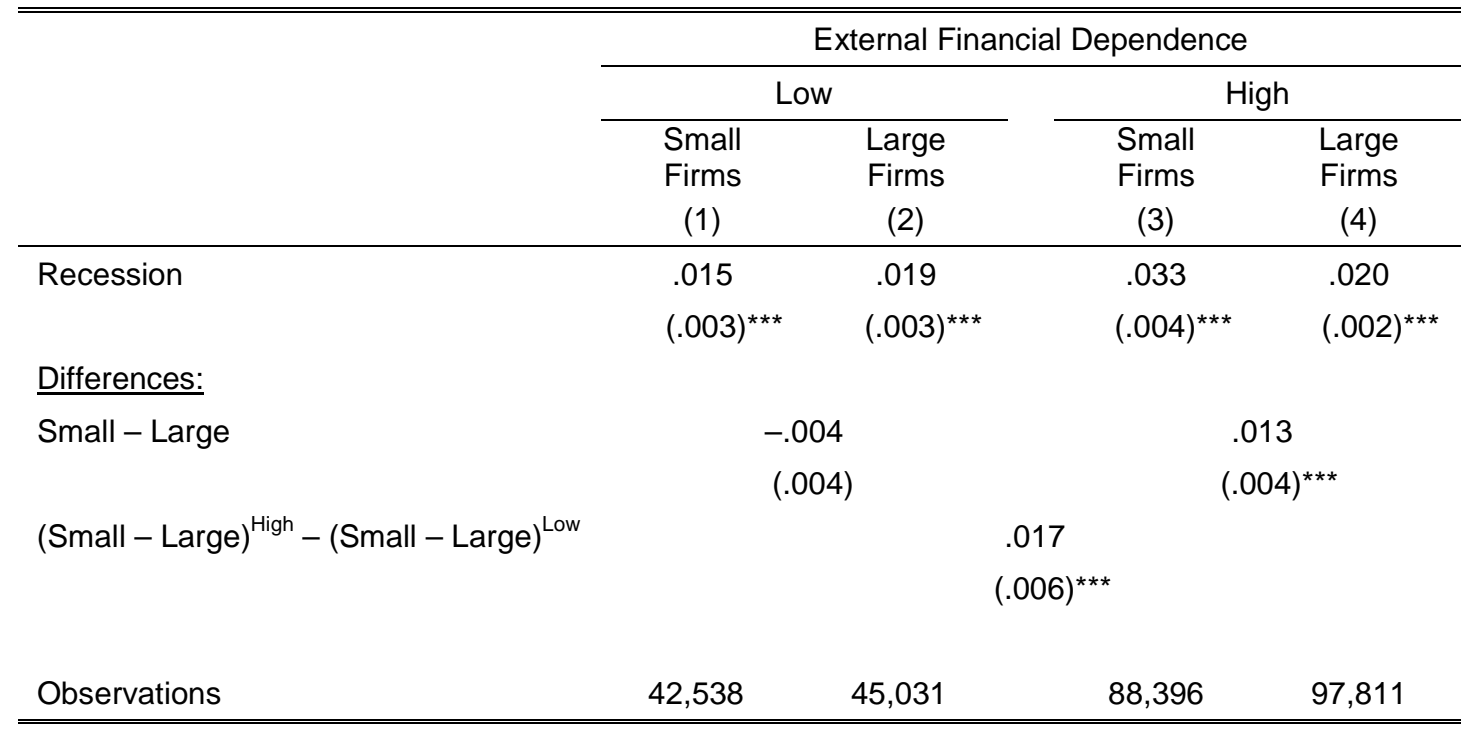

Note - The dependent variable is an indicator that equals to one if a person transitioned from employment to unemployment between years $t-1$ and $t$. The table reports Ordinary Least Squares estimates. All estimates are from a single regression that controls for workers' characteristics and state-industry (2-digit SIC) fixed effects. Workers' characteristics include age, gender, ethnicity, and years of completed education (0-11 years, 12,13-15, or 16). Standard errors are adjusted for clustering at stateindustry (2-digit SIC) level and appear in parentheses. All estimates are weighted by probability sampling weights provided by the CPS. "Recession" equals to one in the years 1991-92 and equals to zero in the years 1988-90. "Small" firms have at most 99 employees. External financial dependence equals the proportion of capital expenditures financed with external funds. A negative value (low external financial dependence) indicates that firms have free cash flow. A positive value indicates that firms must issue debt or equity to finance their investment. External financial dependence is calculated at 2-digit Standard Industrial Classification codes using mature Compustat firms for the period 1980-1996 using the procedures described in Cetorelli and Strahan [2006]. *** indicates statistical significance at the $1 \%$ level. 
Table 6 - Transition to Unemployment following the July 1990 Recession, by Region

\begin{tabular}{|c|c|c|c|c|}
\hline & \multicolumn{4}{|c|}{ External Financial Dependence } \\
\hline & \multicolumn{2}{|c|}{ Low } & \multicolumn{2}{|c|}{ High } \\
\hline & $\begin{array}{c}\text { Small } \\
\text { Firms } \\
(1)\end{array}$ & $\begin{array}{c}\text { Large } \\
\text { Firms } \\
(2)\end{array}$ & $\begin{array}{c}\text { Small } \\
\text { Firms } \\
(3)\end{array}$ & $\begin{array}{c}\text { Large } \\
\text { Firms } \\
(4)\end{array}$ \\
\hline & \multicolumn{4}{|c|}{ Panel A: New England } \\
\hline Recession & $\begin{array}{l}.038 \\
(.009)^{\star \star \star}\end{array}$ & $\begin{array}{l}.026 \\
(.008)^{\star \star \star}\end{array}$ & $\begin{array}{l}.080 \\
(.015)^{\star \star \star}\end{array}$ & $\begin{array}{l}.029 \\
(.008)^{\star \star \star}\end{array}$ \\
\hline \multicolumn{5}{|l|}{ Differences: } \\
\hline Small - Large & \multicolumn{2}{|c|}{$(.012)$} & \multicolumn{2}{|c|}{$(.013)^{\star \star \star}$} \\
\hline$(\text { Small - Large })^{\text {High }}-(\text { Small - Large })^{\text {Low }}$ & \multicolumn{4}{|c|}{.039} \\
\hline \multirow[t]{2}{*}{ Observations } & 4,005 & 4,744 & 8,071 & 8,533 \\
\hline & \multicolumn{4}{|c|}{ Panel B: Rest of the U.S. } \\
\hline Recession & $\begin{array}{c}.013 \\
(.003)^{\star \star \star}\end{array}$ & $\begin{array}{l}.019 \\
(.003)^{\star \star \star}\end{array}$ & $\begin{array}{l}.030 \\
(.004)^{\star \star \star}\end{array}$ & $\begin{array}{l}.019 \\
(.002)^{\star \star \star}\end{array}$ \\
\hline \multicolumn{5}{|l|}{ Differences: } \\
\hline Small - Large & \multicolumn{2}{|c|}{-.005} & $(.004)^{\star \star \star}$ & 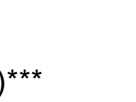 \\
\hline$(\text { Small - Large })^{\text {High }}-(\text { Small - Large })^{\text {Low }}$ & \multicolumn{4}{|c|}{.016} \\
\hline Observations & 38,533 & 40,287 & 80,325 & 89,278 \\
\hline
\end{tabular}

Note - The dependent variable is an indicator that equals to one if a person transitioned from employment to unemployment between years $t-1$ and $t$. Panel A includes only the following states: Connecticut, Maine, Massachusetts, New Hampshire, Rhode Island, and Vermont. Panel B excludes these states. The table reports Ordinary Least Squares estimates. Within each panel, the estimates are from a single regression that controls for workers' characteristics and state-industry (2-digit SIC) fixed effects. Workers' characteristics include age, gender, ethnicity, and years of completed education (0-11 years, 12, 13-15, or 16). The table reports Ordinary Least Squares estimates. Standard errors are adjusted for clustering at state-industry (2-digit SIC) level and appear in parentheses. All estimates are weighted by probability sampling weights provided by the CPS. "Recession" equals to one in the years 1991-92 and equals to zero in the years 1988-90. "Small" firms have at most 99 employees. External financial dependence equals the proportion of capital expenditures financed with external funds. A negative value (low external financial dependence) indicates that firms have free cash flow. A positive value indicates that firms must issue debt or equity to finance their investment. External financial dependence is calculated at 2-digit Standard Industrial Classification codes using mature Compustat firms for the period 1980-1996 using the procedures described in Cetorelli and Strahan [2006]. ** and ${ }^{* * *}$ indicate statistical significance at the $5 \%$ and $1 \%$ levels, respectively. 
Table 7 - Transition to Unemployment following the December 2007 Recession

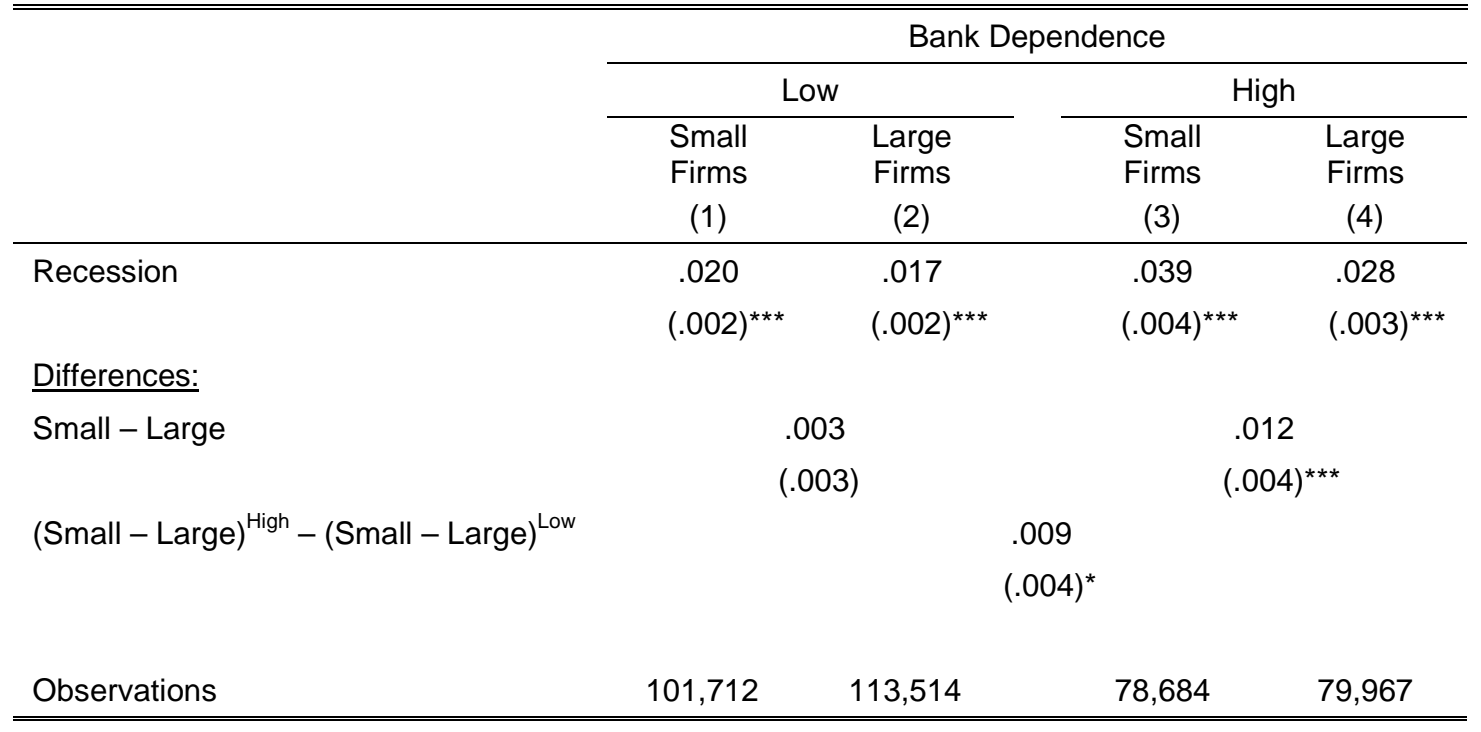

Note - The dependent variable is an indicator that equals to one if a person transitioned from employment to unemployment between years $t-1$ and $t$. The table reports Ordinary Least Squares estimates. All estimates are from a single regression that controls for workers' characteristics and state-industry (2-digit SIC) fixed effects. Workers' characteristics include age, gender, ethnicity, and years of completed education (0-11 years, 12,13-15, or 16). Standard errors are adjusted for clustering at stateindustry (2-digit SIC) level and appear in parentheses. All estimates are weighted by probability sampling weights provided by the CPS. "Recession" equals to one in the years 2008-09 and equals to zero in the years 2005-07. "Small" firms have at most 99 employees. Bank dependence is the share of assets financed with debt. We use the 1998 Survey of Small Business Finance (SSBF) to calculate measures of bank dependence for each 2-digit SIC industry. Industries with"low" bank dependence are industries with below median share of assets financed with debt. "High" bank dependence industries have above median share of assets financed with debt. * and *** indicate statistical significance at the $10 \%$ and $1 \%$ levels, respectively. 
Table 8 - The Impact of the December 2007 Recession on Log Establishments Per Capita

\begin{tabular}{|c|c|c|c|c|}
\hline & \multicolumn{4}{|c|}{ External Financial Dependence } \\
\hline & \multicolumn{2}{|c|}{ Low } & \multicolumn{2}{|c|}{ High } \\
\hline & $\begin{array}{c}\text { Small } \\
\text { Firms } \\
(1)\end{array}$ & $\begin{array}{l}\text { Large } \\
\text { Firms } \\
(2)\end{array}$ & $\begin{array}{c}\text { Small } \\
\text { Firms } \\
(3)\end{array}$ & $\begin{array}{l}\text { Large } \\
\text { Firms } \\
(4)\end{array}$ \\
\hline Recession & $\begin{array}{l}-.035 \\
(.005)^{\star \star \star}\end{array}$ & $\begin{array}{l}-.036 \\
(.004)^{\star \star \star}\end{array}$ & $\begin{array}{l}-.052 \\
(.002)^{\star \star \star}\end{array}$ & $\begin{array}{l}-.040 \\
(.003)^{\star \star \star}\end{array}$ \\
\hline \multicolumn{5}{|l|}{ Differences: } \\
\hline $\begin{array}{l}\text { Small - Large } \\
(\text { Small - Large })^{\text {High }}-(\text { Small - Large })^{\text {Low }}\end{array}$ & . & - & - & $\star \star \star *$ \\
\hline Observations & 37,635 & 30,108 & 67,210 & 53,768 \\
\hline $\begin{array}{l}\text { Note - The dependent variable is the natural logari } \\
\text { reports Ordinary Least Squares estimates. All estin } \\
\text { fixed effects. Standard errors are adjusted for cl } \\
\text { "Recession" equals to one in the years } 2008-09 \text { an } \\
\text { External financial dependence equals the proporti } \\
\text { external financial dependence) indicates that firms } \\
\text { to finance their investment. External financial dep } \\
\text { mature Compustat firms for the period } 1980-1996 \\
\text { between the industrial codes in Compustat and the } \\
\text { 3. Number of establishments is from County Busi } \\
\text { Census Bureau. }{ }^{* \star} \text { and }{ }^{* \star \star} \text { indicate statistical signific }\end{array}$ & $\begin{array}{l}\text { of the number } \\
\text { sare from a sir } \\
\text { ing at the stat } \\
\text { uals to zero in } \\
\text { f capital exper } \\
\text { free cash flow. } \\
\text { nce is calculat } \\
\text { g the procedu } \\
\text { strial codes in th } \\
\text { Patterns for th } \\
\text { at the } 5 \% \text { and }\end{array}$ & $\begin{array}{l}\text { ablishment per } \\
\text { egression that } \\
\text { ustry (3-digit N, } \\
\text { ears 2005-07." } \\
\text { es financed wit } \\
\text { sitive value ind } \\
\text { a 2-digit Stanc } \\
\text { escribed in Ce } \\
\text { unty Business } \\
\text { ars 2005-2009. } \\
\text { evels, respectiv }\end{array}$ & $\begin{array}{l}\text { an industry/stc } \\
\text { for state-indust } \\
\text { evel and appea } \\
\text { firms have at m } \\
\text { nal funds. A ne } \\
\text { hat firms must is } \\
\text { lustrial Classific } \\
\text { ind Strahan }[20 \\
5 \text { is detailed in th } \\
\text { ation estimates }\end{array}$ & $\begin{array}{l}\text { ear. The table } \\
\text { 3-digit NAICS) } \\
\text { parentheses. } \\
9 \text { employees. } \\
\text { ve value (low } \\
\text { debt or equity } \\
\text { codes using } \\
\text { The mapping } \\
\text { ppendix Table } \\
\text { from the U.S. }\end{array}$ \\
\hline
\end{tabular}


Appendix Table 1 - Basic Results without the Construction Sector

\begin{tabular}{|c|c|c|c|c|}
\hline & \multicolumn{4}{|c|}{ External Financial Dependence } \\
\hline & \multicolumn{2}{|c|}{ Low } & \multicolumn{2}{|c|}{ High } \\
\hline & $\begin{array}{l}\text { Small } \\
\text { Firms } \\
(1) \\
\end{array}$ & $\begin{array}{c}\text { Large } \\
\text { Firms } \\
(2) \\
\end{array}$ & $\begin{array}{l}\text { Small } \\
\text { Firms } \\
(3)\end{array}$ & $\begin{array}{c}\text { Large } \\
\text { Firms } \\
(4)\end{array}$ \\
\hline Recession & $\begin{array}{l}.020 \\
(.002)^{\star \star \star}\end{array}$ & $\begin{array}{l}.021 \\
(.003)^{\star \star \star}\end{array}$ & $\begin{array}{l}.024 \\
(.002)^{\star \star \star}\end{array}$ & $\begin{array}{l}.018 \\
(.002)^{\star \star \star}\end{array}$ \\
\hline \multicolumn{5}{|l|}{ Differences: } \\
\hline $\begin{array}{l}\text { Small - Large } \\
(\text { Small - Large })^{\text {High }}-(\text { Small - Large })^{\text {Low }}\end{array}$ & \multicolumn{2}{|c|}{$\begin{array}{r}-.001 \\
(.004)\end{array}$} & \multicolumn{2}{|c|}{$\begin{array}{l}.007 \\
(.002)^{\star \star \star}\end{array}$} \\
\hline Observations & 61,572 & 61,860 & 88,869 & 123,774 \\
\hline $\begin{array}{l}\text { Note - This table excludes the Construction sect } \\
\text { transitioned from employment to unemployment bet } \\
\text { estimates are from a single regression that contr } \\
\text { Workers' characteristics include age, gender, ethnic } \\
\text { errors are adjusted for clustering at state-industry } \\
\text { probability sampling weights provided by the CPS. " } \\
\text { 2005-07. "Small" firms have at most } 99 \text { employees } \\
\text { financed with external funds. A negative value (lo } \\
\text { positive value indicates that firms must issue debt o } \\
\text { at 2-digit Standard Industrial Classification codes } \\
\text { described in Cetorelli and Strahan [2006]. * and }{ }^{* * *} \text { in }\end{array}$ & $\begin{array}{l}\text { The depender } \\
\text { en years } t-1 \text { an } \\
\text { for workers' cl } \\
\text { and years of cc } \\
\text { digit SIC) level } \\
\text { cession" equals } \\
\text { xternal financia } \\
\text { external financia } \\
\text { quity to finance } \\
\text { g mature Comp } \\
\text { cate statistical s }\end{array}$ & $\begin{array}{l}\text { riable is an i } \\
\text { The table repo } \\
\text { cteristics and } \\
\text { eted education } \\
\text { appear in par } \\
\text { ne in the years } \\
\text { pendence equ } \\
\text { pendence) ind } \\
\text { investment. E } \\
\text { t firms for the } \\
\text { cance at the } 1\end{array}$ & $\begin{array}{l}\text { that equals to } \\
\text { ary Least Squ } \\
\text { ustry (2-digit } \\
\text { ars, 12, 13-15 } \\
\text { All estimate } \\
\text { and equals tc } \\
\text { oportion of ca } \\
\text { at firms have } \\
\text { lancial depend } \\
\text { 980-1996 usir } \\
\% \text { levels, resp }\end{array}$ & $\begin{array}{l}\text { e if a person } \\
\text { estimates. All } \\
\text { fixed effects. } \\
\text { 16). Standard } \\
\text { e weighted by } \\
\text { ro in the years } \\
\text { I expenditures } \\
\text { cash flow. A } \\
\text { e is calculated } \\
\text { he procedures } \\
\text { vely. }\end{array}$ \\
\hline
\end{tabular}


Appendix Table 2 - External Financial Dependence by Industrial Sectors

\begin{tabular}{lcc}
\hline \hline Industry & SIC & EFD \\
\hline Forestry & -4.63 \\
Insurance carriers & -33 & -3.96 \\
Leather and leather products & 31 & -0.96 \\
Tobacco products & -21 & -0.92 \\
Apparel and other finished products made from fabrics and similar materials & -0.61 \\
Educational services & 23 & -0.55 \\
Social services & -0.43 \\
Miscellaneous repair services & 83 \\
Food and kindred products & -0.25 \\
Fabricated metal products, except machinery and transportation equipment & -0.24 \\
Furniture and fixtures & 20 \\
Stone, clay, glass, and concrete products & 34 \\
Miscellaneous manufacturing industries & -0.24 \\
Apparel and accessory stores & -0.23 \\
Business services & 25 \\
Local and suburban transit and interurban highway passenger transportation & 32 \\
Personal services & -0.20 \\
Printing, publishing, and allied industries & 39 \\
Communications & -0.20 \\
Engineering, accounting, research, management, and related services & -0.16 \\
Measuring, analyzing, and controlling instruments; photographic, medical, and optical goods & -0.16 \\
\hline \hline
\end{tabular}

Note - This table reports measures of external financial dependence for each industry at the 2-digit SIC category. External financial dependence equals the proportion of capital expenditures financed with external funds. A negative value indicates that firms have free cash flow, whereas a positive value indicates that firms must issue debt or equity to finance their investment. External financial dependence is calculated using mature COMPUSTAT firms for the period 1980-1996. Mature firms are firms that have been on Compustat for at least 10 years. 
Appendix Table 2 - External Financial Dependence by Industrial Sectors (cont.)

\begin{tabular}{|c|c|c|}
\hline Industry & $\mathrm{SIC}$ & EFD \\
\hline Transportation equipment & 37 & 0.00 \\
\hline Transportation services & 47 & 0.01 \\
\hline Industrial and commercial machinery and computer equipment & 35 & 0.01 \\
\hline Primary metal industries & 33 & 0.03 \\
\hline Agriculture & $01-02-07$ & 0.03 \\
\hline Railroad transportation & 40 & 0.04 \\
\hline Lumber and wood products, except furniture & 24 & 0.04 \\
\hline Rubber and miscellaneous plastics products & 30 & 0.04 \\
\hline Mining and quarrying of nonmetallic minerals, except fuels & 14 & 0.05 \\
\hline Paper and allied products & 26 & 0.06 \\
\hline Petroleum refining and related industries & 29 & 0.09 \\
\hline Wholesale trade: non-durable goods & 51 & 0.10 \\
\hline Textile mill products & 22 & 0.10 \\
\hline Motor freight transportation and warehousing & 42 & 0.10 \\
\hline General merchandise stores & 53 & 0.12 \\
\hline Coal mining & 12 & 0.13 \\
\hline Miscellaneous retail & 59 & 0.16 \\
\hline Food stores & 54 & 0.16 \\
\hline Motion pictures & 78 & 0.17 \\
\hline Amusement and recreation services & 79 & 0.21 \\
\hline Electronic and other electrical equipment and components, except computer equipment & 36 & 0.22 \\
\hline Electric, gas, and sanitary services & 49 & 0.24 \\
\hline Eating and drinking places & 58 & 0.25 \\
\hline Chemicals and allied products & 28 & 0.28 \\
\hline Fishing, hunting, and trapping & 09 & 0.31 \\
\hline Wholesale trade: durable goods & 50 & 0.32 \\
\hline Health services & 80 & 0.35 \\
\hline Real estate & 65 & 0.38 \\
\hline Hotels, rooming houses, camps, and other lodging places & 70 & 0.38 \\
\hline Oil and gas extraction & 13 & 0.40 \\
\hline Automotive dealers and gasoline service stations & 55 & 0.41 \\
\hline Automotive repair, services, and parking & 75 & 0.43 \\
\hline Building materials, hardware, garden supply, and mobile home dealers & 52 & 0.47 \\
\hline Transportation by air & 45 & 0.48 \\
\hline Construction & $15-16-17$ & 0.57 \\
\hline Water transportation & 44 & 0.67 \\
\hline Home furniture, furnishings, and equipment stores & 57 & 0.69 \\
\hline Metal mining & 10 & 0.96 \\
\hline Pipelines, except natural gas & 46 & 1.00 \\
\hline
\end{tabular}

Note - This table reports measures of external financial dependence for each industry at the 2-digit SIC category. External financial dependence equals the proportion of capital expenditures financed with external funds. A negative value indicates that firms have free cash flow, whereas a positive value indicates that firms must issue debt or equity to finance their investment. External financial dependence is calculated using mature COMPUSTAT firms for the period 1980-1996. Mature firms are firms that have been on Compustat for at least 10 years. 
Appendix Table 3 - Mapping Industrial Codes between Compustat and QCEW/CBP

\begin{tabular}{|c|c|}
\hline Industry (2-digit SIC code) & Industry (3-digit NAICS code) \\
\hline Agricultural Production - Crops (1) & Crop Production (111) \\
\hline Agricultural Production - Livestock (2) & Animal Production (112) \\
\hline Agricultural Services (7) & Support Activities for Agriculture and Forestry (115) \\
\hline Forestry (8) & Forestry and Logging (113) \\
\hline Fishing, Hunting, and Trapping (9) & Fishing, Hunting and Trapping (114) \\
\hline $\begin{array}{l}\text { Metal Mining (10); Coal Mining (12); Nonmetallic } \\
\text { Minerals, except Fuels (14) }\end{array}$ & $\begin{array}{l}\text { Mining, except Oil and Gas (212); Support Activities for Mining } \\
\text { (213) }\end{array}$ \\
\hline Oil and Gas Extraction (13) & Oil and Gas Extraction (211) \\
\hline General Building Contractors (15) & Construction of Buildings (236) \\
\hline Heavy Construction Contractors (16) & Heavy and Civil Engineering Construction (237) \\
\hline Special Trade Contractors (17) & Specialty Trade Contractors (238) \\
\hline Food and Kindred Products (20) & Food Manufacturing (311) \\
\hline Tobacco Manufactures (21) & Beverage and Tobacco Product Manufacturing (312) \\
\hline Textile Mill Products (22) & Textile Mills (313); Textile Product Mills (314) \\
\hline Apparel and Other Textile Products (23) & Apparel Manufacturing (315) \\
\hline Lumber and Wood Products (24) & Wood Product Manufacturing (321) \\
\hline Furniture and Fixtures (25) & Furniture and Related Product Manufacturing (337) \\
\hline Paper and Allied Products (26) & Paper Manufacturing (322) \\
\hline Printing and Publishing (27) & $\begin{array}{l}\text { Printing and Related Support Activities (323); Publishing } \\
\text { Industries, except Internet (511); Internet Publishing and } \\
\text { Broadcasting (516) }\end{array}$ \\
\hline Chemicals and allied products (28) & Chemical Manufacturing (325) \\
\hline Petroleum and coal products (29) & Petroleum and Coal Products Manufacturing (324) \\
\hline
\end{tabular}


Rubber and Miscellaneous Plastics Products (30)

Leather and Leather Products (31)

Stone, Clay, Glass, and Concrete Products (32)

Primary Metal Industries (33)

Fabricated Metal Products (34)

Industrial Machinery and Equipment (35); Electrical and Electronic Equipment (36); Instruments and Related Products (38)

Transportation Equipment (37)

Miscellaneous Manufacturing Industries (39)

Railroad Transportation (40)

Local and Interurban Passenger Transit (41)

Motor Freight Transportation and Warehousing (42)

Water Transportation (44)

Transportation by Air (45)

Pipelines, except Natural Gas (46)

Transportation Services (47)

Communications (48)

Electric, Gas, and Sanitary Services (49)

Wholesale Trade - Durable goods (50)

Wholesale Trade - Nondurable Goods (51)

Building Materials, Hardware, Garden Supply, and Mobile Home Dealers (52)
Plastics and Rubber Products Manufacturing (326)

Leather and Allied Product Manufacturing (316)

Nonmetallic Mineral Product Manufacturing (327)

Primary Metal Manufacturing (331)

Fabricated Metal Product Manufacturing (332)

Machinery Manufacturing (333); Computer and Electronic Product Manufacturing (334); Electrical Equipment, Appliance, and Component Manufacturing (335)

Transportation Equipment Manufacturing (336)

Miscellaneous Manufacturing (339)

Rail Transportation (482)

Transit and Ground Passenger Transportation (485)

Truck Transportation (484); Couriers and Messengers (492); Warehousing and Storage (493)

Water Transportation (483)

Air Transportation (481)

Pipeline Transportation (486)

Support Activities for Transportation (488)

Broadcasting, except Internet (515); Telecommunications (517)

Utilities (221); Waste Management and Remediation Services (562)

Merchant Wholesalers, Durable Goods (423); Wholesale Electronic Markets and Agents and Brokers (425)

Merchant Wholesalers, Nondurable Goods (424)

Building Material and Garden Equipment and Supplies Dealers (444) 
General Merchandise Stores (53)

Food Stores (54)

Automotive Dealers and Gasoline Service Stations (55)

Apparel and Accessory Stores (56)

Furniture, Home Furnishings and Equipment Stores (57)

Eating and Drinking Places (58)

Miscellaneous Retail (59)

Security, Commodity Brokers, and Services (62)

Insurance carriers (63); Insurance Agents, Brokers, and Service (64)

Real Estate (65)

Holding and Other Investment Offices (67)

Hotels, Rooming Houses, Camps, and Other Lodging

Places (70)

Personal Services (72)

Business Services (73)

Automotive Repair, Services, and Parking (75);

Miscellaneous Repair Services (76)

Motion Pictures (78)

Amusement and Recreational Services (79)

Health Services (80)
General Merchandise Stores (452)

Food and Beverage Stores (445)

Motor Vehicle and Parts Dealers (441); Gasoline Stations (447)

Clothing and Clothing Accessories Stores (448)

Furniture and Home Furnishings Stores (442); Electronics and Appliance Stores (443)

Food Services and Drinking Places (722)

Health and Personal Care Stores (446); Sporting Goods, Hobby, Book, and Music Stores (451); Miscellaneous Store Retailers (453); Non-store Retailers (454)

Securities, Commodity Contracts, and Other Financial Investments and Related Activities (523)

Insurance Carriers and Related Activities (524)

Real Estate (531)

Lessors of Nonfinancial Intangible Assets, except Copyrighted Works (533); Management of Companies and Enterprises (551)

Accommodation (721)

Personal and Laundry Services (812)

Internet Service Providers, Web Search Portals, and Data Processing Services (518); Other Information Services (519); Rental and Leasing Services (532); Administrative and Support Services (561)

Repair and Maintenance (811)

Motion Picture and Sound Recording Industries (512)

Scenic and Sightseeing Transportation (487); Performing Arts, Spectator Sports, and Related Industries (711); Amusement, Gambling, and Recreation Industries (713)

Ambulatory Health Care Services (621); Hospitals (622); Nursing and Residential Care Facilities (623) 
Educational Services (82)

Social Services (83)

Museums, Art Galleries, Botanical and Zoological

Garden (84)

Engineering and Management Services (87)
Educational Services (611)

Social Assistance (624)

Museums, Historical Sites, and Similar Institutions (712)

Professional, Scientific, and Technical Services (541)

Note - The table lists the mapping of 2-digit SIC industries in Compustat to industrial codes in the Quarterly Census of Employment and Wages and County Business Patterns. 
Appendix Table 4 - Mapping Industrial Codes between Compustat and the Current Population Survey

\begin{tabular}{|c|c|}
\hline Industry (2-digit SIC code) & Industry (3-digit Industrial Code from the CPS) \\
\hline $\begin{array}{l}\text { Agricultural Production-Crops (1); Agricultural } \\
\text { Production-Livestock (2); Agricultural Services (7) }\end{array}$ & Agriculture (105) \\
\hline Forestry (8) & Forestry (116) \\
\hline Fishing, hunting, and trapping (9) & Fisheries (126) \\
\hline Metal mining $(10)$ & Metal mining (206) \\
\hline Coal mining (12) & Coal mining (216) \\
\hline Oil and gas extraction (13) & Crude petroleum and natural gas extraction (226) \\
\hline Nonmetallic minerals, except fuels (14) & Nonmetallic mining and quarrying, except fuel (236) \\
\hline $\begin{array}{l}\text { General Building Contractors (15); Heavy Construction } \\
\text { Contractors (16) }\end{array}$ & Construction (246) \\
\hline Food and kindred products (20) & $\begin{array}{l}\text { Meat products (406); Dairy products (407); Canning and } \\
\text { preserving fruits, vegetables, and sea foods (408); Grain-mill } \\
\text { products (409); Bakery products (416); Confectionery and } \\
\text { related products (417); Beverage industries (418); } \\
\text { Miscellaneous food preparations and kindred products (419); } \\
\text { Not specified food industries (426) }\end{array}$ \\
\hline Tobacco manufactures (21) & Tobacco manufactures (429) \\
\hline Textile mill products (22) & $\begin{array}{l}\text { Knitting mills (436); Dyeing and finishing textiles, except knit } \\
\text { goods (437); Carpets, rugs, and other floor coverings (438); } \\
\text { Yarn, thread, and fabric mills (439); Miscellaneous textile mill } \\
\text { products (446); Synthetic fibers (466) }\end{array}$ \\
\hline Apparel and other textile products (23) & $\begin{array}{l}\text { Apparel and accessories (448); Miscellaneous fabricated } \\
\text { textile products (449) }\end{array}$ \\
\hline Lumber and wood products (24) & $\begin{array}{l}\text { Logging (306); Sawmills, planing mills, and millwork (307); } \\
\text { Miscellaneous wood products (308) }\end{array}$ \\
\hline Furniture and fixtures (25) & Furniture and fixtures (309) \\
\hline Paper and allied products (26) & $\begin{array}{l}\text { Pulp, paper, and paperboard mills (456); Paperboard } \\
\text { containers and boxes (457); Miscellaneous paper and pulp } \\
\text { products (458) }\end{array}$ \\
\hline Printing and publishing (27) & Printing, publishing, and allied industries (459) \\
\hline Chemicals and allied products (28) & $\begin{array}{l}\text { Drugs and medicines (467); Paints, varnishes, and related } \\
\text { products (468); Miscellaneous chemicals and allied products } \\
(469)\end{array}$ \\
\hline Petroleum and coal products (29) & $\begin{array}{l}\text { Petroleum refining (476); Miscellaneous petroleum and coal } \\
\text { products (477) }\end{array}$ \\
\hline
\end{tabular}


Rubber and miscellaneous plastics products (30)

Leather and leather products (31)

Stone, clay, glass, and concrete products (32)

Primary metal industries (33)

Fabricated metal products (34)

Industrial machinery and equipment (35)

Electrical and electronic equipment (36)

Transportation equipment (37)

Instruments and related products (38)

Miscellaneous manufacturing industries (39)

Railroad Transportation (40)

Local and interurban passenger transit (41)

Motor freight transportation and warehousing (42)

U.S. Postal Service (43)

Water transportation (44)

Transportation by air (45)

Pipelines, except natural gas (46)

Transportation services (47)

Communications (48)

Electric, gas, and sanitary services (49)
Rubber products (478)

Leather: tanned, curried, and finished (487); Footwear, except rubber (488); Leather products, except footwear (489)

Glass and glass products (316); Cement, concrete, gypsum and plaster products (317); Structural clay products (318); Pottery and related products (319); Miscellaneous nonmetallic mineral and stone products (326)

Blast furnaces, steel works, and rolling mills (336); Other primary iron and steel industries (337); Primary nonferrous industries (338); Not specified metal industries (348)

Fabricated steel products (346); Fabricated nonferrous metal products (347)

Agricultural machinery and tractors (356); Office and store machines and devices (357); Miscellaneous machinery (358)

Electrical machinery, equipment, and supplies (367)

Motor vehicles and motor vehicle equipment (376); Aircraft and parts (377); Ship and boat building and repairing (378); Railroad and miscellaneous transportation equipment (379)

Professional equipment and supplies (386); Photographic equipment and supplies (387); Watches, clocks, and clockwork-operated devices (388)

Miscellaneous manufacturing industries (399); Not specified manufacturing industries (499)

Railroads and railway express service (506)

Street railways and bus lines (516); Taxicab service (536)

Trucking service (526); Warehousing and storage (527)

Postal service (906)

Water transportation (546)

Air transportation (556)

Petroleum and gasoline pipe lines (567)

Services incidental to transportation (568)

Telephone (578); Telegraph (579); Radio broadcasting and television (856)

Electric light and power (586); Gas and steam supply systems (587); Electric-gas utilities (588); Water supply (596); Sanitary services (597); Other and not specified utilities (598) 
Wholesale trade--durable goods (50)

Wholesale trade--nondurable goods (51)

Building materials, hardware, garden supply, \& mobile

General merchandise stores (53)

Food stores (54)

Automotive dealers and gasoline service stations (55)

Apparel and accessory stores (56)

Furniture, home furnishings and equipment stores (57)

Eating and drinking places (58)

Miscellaneous retail (59)

Depository Institutions (60); Non-depository Credit Institutions (61)

Security, commodity brokers, and services (62)

Insurance carriers (63)

Real estate (65)

Hotels, rooming houses, camps, and other lodging plac (70)

Personal services (72)

Business services (73)

Automotive repair, services, and parking (75)

Miscellaneous repair services (76)
Motor vehicles and equipment (606); Electrical goods, hardware, and plumbing equipment (616); Machinery, equipment, and supplies (617)

Drugs, chemicals, and allied products (607); Dry goods apparel (608); Food and related products (609); Petroleum products (618); Farm products--raw materials (619)

Hardware and farm implement stores (686); Lumber and building material retailing (687)

General merchandise stores (646); Five and ten cent stores (647)

Food stores, except dairy products (636); Dairy products stores and milk retailing (637)

Motor vehicles and accessories retailing (667); Gasoline service stations (668)

Apparel and accessories stores, except shoe (656); Shoe stores (657)

Furniture and house furnishing stores (658); Household appliance and radio stores (659)

Eating and drinking places (679)

Drug stores (669); Liquor stores (688); Retail florists (689); Jewelry stores (696); Fuel and ice retailing (697);

Miscellaneous retail stores (698); Not specified retail trade (699)

Banking and credit agencies (716)

Security and commodity brokerage and investment companies (726)

Insurance (736)

Real estate (746)

Hotels and lodging places (836)

Laundering, cleaning, and dyeing services (846); Dressmaking shops (847); Shoe repair shops (848); Miscellaneous personal services (849)

Advertising (806); Miscellaneous business services (808)

Auto repair services and garages (816)

Miscellaneous repair services (817) 
Motion pictures (78)

Amusement and recreational services (79)

Amusement and recreational services (79)

Health services (80)

Legal services (81)

Educational services (82)

Social services (83)

Membership organizations (86)

Engineering and management services (87)

Private households (88)

Miscellaneous services (89)

Agricultural Production--Crops (1); Agricultural Production-Livestock (2); Agricultural Services (7)

Forestry (8)

Fishing, hunting, and trapping (9)

Metal mining (10)

Coal mining (12)

Oil and gas extraction (13)

Nonmetallic minerals, except fuels (14)

General Building Contractors (15); Heavy Construction Contractors (16)

Food and kindred products (20)

Tobacco manufactures (21)

Textile mill products (22)

Apparel and other textile products (23)
Theaters and motion pictures (857)

Bowling alleys, and billiard and pool parlors (858)

Miscellaneous entertainment and recreation services (859)

Medical and other health services, except hospitals (868); Hospitals (869)

Legal services (879)

Educational services (888)

Welfare and religious services (896)

Nonprofit membership organizations (897)

Accounting, auditing, and bookkeeping services (807);

Engineering and architectural services (898)

Private households (826)

Miscellaneous professional and related services (899)

Agriculture (105)

Forestry (116)

Fisheries (126)

Metal mining (206)

Coal mining (216)

Crude petroleum and natural gas extraction (226)

Nonmetallic mining and quarrying, except fuel (236)

Construction (246)

Meat products (406); Dairy products (407); Canning and preserving fruits, vegetables, and seafoods (408); Grain-mill products (409); Bakery products (416); Confectionery and related products (417); Beverage industries (418);

Miscellaneous food preparations and kindred products (419); Not specified food industries (426)

Tobacco manufactures (429)

Knitting mills (436); Dyeing and finishing textiles, except knit goods (437); Carpets, rugs, and other floor coverings (438); Yarn, thread, and fabric mills (439); Miscellaneous textile mill products (446); Synthetic fibers (466)

Apparel and accessories (448); Miscellaneous fabricated 
Lumber and wood products (24)

Furniture and fixtures (25)

Paper and allied products (26)

Printing and publishing (27)

Chemicals and allied products (28)

Petroleum and coal products (29)

Rubber and miscellaneous plastics products (30)

Leather and leather products (31)

Stone, clay, glass, and concrete products (32)

Primary metal industries (33)

Fabricated metal products (34)

Industrial machinery and equipment (35)

Electrical and electronic equipment (36)

Transportation equipment (37)

Instruments and related products (38)

Miscellaneous manufacturing industries (39)

Railroad Transportation (40)

Local and interurban passenger transit (41) textile products (449)

Logging (306); Sawmills, planing mills, and millwork (307); Misc wood products (308)

Furniture and fixtures (309)

Pulp, paper, and paperboard mills (456); Paperboard containers and boxes (457); Miscellaneous paper and pulp products (458)

Printing, publishing, and allied industries (459)

Drugs and medicines (467); Paints, varnishes, and related products (468); Miscellaneous chemicals and allied products (469)

Petroleum refining (476); Miscellaneous petroleum and coal products (477)

Rubber products (478)

Leather: tanned, curried, and finished (487); Footwear, except rubber (488); Leather products, except footwear (489)

Glass and glass products (316); Cement, concrete, gypsum and plaster products (317); Structural clay products (318); Pottery and related products (319); Miscellaneous nonmetallic mineral and stone products (326)

Blast furnaces, steel works, and rolling mills (336); Other primary iron and steel industries (337); Primary nonferrous industries (338); Not specified metal industries (348)

Fabricated steel products (346); Fabricated nonferrous metal products (347)

Agricultural machinery and tractors (356); Office and store machines and devices (357); Miscellaneous machinery (358)

Electrical machinery, equipment, and supplies (367)

Motor vehicles and motor vehicle equipment (376); Aircraft and parts (377); Ship and boat building and repairing (378); Railroad and miscellaneous transportation equipment (379)

Professional equipment and supplies (386); Photographic equipment and supplies (387); Watches, clocks, and clockwork-operated devices (388)

Miscellaneous manufacturing industries (399); Not specified manufacturing industries (499)

Railroads and railway express service (506)

Street railways and bus lines (516); Taxicab service (536) 
Motor freight transportation and warehousing (42)

U.S. Postal Service (43)

Water transportation (44)

Transportation by air (45)

Pipelines, except natural gas (46)

Transportation services (47)

Communications (48)

Electric, gas, and sanitary services (49)

Wholesale trade--durable goods (50)

Wholesale trade--nondurable goods (51)

Building materials, hardware, garden supply, \& mobile

General merchandise stores (53)

Food stores (54)

Automotive dealers and gasoline service stations (55)

Apparel and accessory stores (56)

Furniture, home furnishings and equipment stores (57)

Eating and drinking places (58)

Miscellaneous retail (59)

Depository Institutions (60); Non-depository Credit Institutions (61)
Trucking service (526); Warehousing and storage (527)

Postal service (906)

Water transportation (546)

Air transportation (556)

Petroleum and gasoline pipe lines (567)

Services incidental to transportation (568)

Telephone (578); Telegraph (579); Radio broadcasting and television (856)

Electric light and power (586); Gas and steam supply systems (587); Electric-gas utilities (588); Water supply (596); Sanitary services (597); Other and not specified utilities (598)

Motor vehicles and equipment (606); Electrical goods, hardware, and plumbing equipment (616); Machinery, equipment, and supplies (617)

Drugs, chemicals, and allied products (607); Dry goods apparel (608); Food and related products (609); Petroleum products (618); Farm products--raw materials (619)

Hardware and farm implement stores (686); Lumber and building material retailing (687)

General merchandise stores (646); Five and ten cent stores (647)

Food stores, except dairy products (636); Dairy products stores and milk retailing (637)

Motor vehicles and accessories retailing (667); Gasoline service stations (668)

Apparel and accessories stores, except shoe (656); Shoe stores (657)

Furniture and house furnishing stores (658); Household appliance and radio stores (659)

Eating and drinking places (679)

Drug stores (669); Liquor stores (688); Retail florists (689); Jewelry stores (696); Fuel and ice retailing (697);

Miscellaneous retail stores (698); Not specified retail trade (699)

Banking and credit agencies (716) 
Security, commodity brokers, and services

Insurance carriers (63)

Real estate (65)

Hotels, rooming houses, camps, and other lodging places (70)

Personal services (72)

Business services (73)
Security and commodity brokerage and investment companies (726)

Insurance (736)

Real estate (746)

Hotels and lodging places (836)

Laundering, cleaning, and dyeing services (846); Dressmaking shops (847); Shoe repair shops (848); Miscellaneous personal services (849)

Advertising (806); Miscellaneous business services (808)

Note - The table lists the mapping of 2-digit SIC industries in Compustat to the 1950 Census industrial codes in IPUMS Current Population Survey files. 